\title{
Why does democracy need education?
}

\section{Citation}

Glaeser, Edward L., Giacomo A. M. Ponzetto, and Andrei Shleifer. 2007. “Why Does Democracy Need Education?" J Econ Growth 12 (2) (May 31): 77-99. doi:10.1007/s10887-007-9015-1.

\section{Published Version}

doi:10.1007/s10887-007-9015-1

\section{Permanent link}

http://nrs.harvard.edu/urn-3:HUL.InstRepos:27867132

\section{Terms of Use}

This article was downloaded from Harvard University's DASH repository, and is made available under the terms and conditions applicable to Other Posted Material, as set forth at http:// nrs.harvard.edu/urn-3:HUL.InstRepos:dash.current.terms-of-use\#LAA

\section{Share Your Story}

The Harvard community has made this article openly available.

Please share how this access benefits you. Submit a story.

Accessibility 
NBER WORKING PAPER SERIES

WHY DOES DEMOCRACY NEED EDUCATION?

Edward L. Glaeser

Giacomo Ponzetto

Andrei Shleifer

Working Paper 12128

http://www.nber.org/papers/w12128

\author{
NATIONAL BUREAU OF ECONOMIC RESEARCH \\ 1050 Massachusetts Avenue \\ Cambridge, MA 02138 \\ March 2006
}

Glaeser thanks the Taubman Center for State and Local Government. Ponzetto thanks the Marco Fanno and the Mario Gasbarri Foundations. We are grateful to Timothy Besley, Filipe Campante, Ruben Enikolopov, Nicola Gennaioli, Elhanan Helpman, Elias Papaiouannou, Richard Posner, and Sidney Verba for comments, and to Josh Gottlieb for outstanding research assistance. The views expressed herein are those of the author(s) and do not necessarily reflect the views of the National Bureau of Economic Research.

(C2006 by Edward L. Glaeser, Giacomo Ponzetto and Andrei Shleifer. All rights reserved. Short sections of text, not to exceed two paragraphs, may be quoted without explicit permission provided that full credit, including () notice, is given to the source. 
Why Does Democracy Need Education?

Edward L. Glaeser, Giacomo Ponzetto and Andrei Shleifer

NBER Working Paper No. 12128

March 2006

JEL No. D72, D74, H11

\begin{abstract}
Across countries, education and democracy are highly correlated. We motivate empirically and then model a causal mechanism explaining this correlation. In our model, schooling teaches people to interact with others and raises the benefits of civic participation, including voting and organizing. In the battle between democracy and dictatorship, democracy has a wide potential base of support but offers weak incentives to its defenders. Dictatorship provides stronger incentives to a narrower base. As education raises the benefits of civic participation, it raises the support for more democratic regimes relative to dictatorships. This increases the likelihood of democratic revolutions against dictatorships, and reduces that of successful anti-democratic coups.
\end{abstract}

\author{
Andrei Shleifer \\ Department of Economics \\ Harvard University \\ Littauer Center M-9 \\ Cambridge, MA 02138 \\ and NBER \\ ashleifer@harvard.edu \\ Edward L. Glaeser \\ Department of Economics \\ 315A Littauer Center \\ Harvard University \\ Cambridge, MA 02138 \\ and NBER \\ eglaeser@harvard.edu \\ Giacomo Ponzetto \\ Harvard University \\ Department of Economics \\ Littauer Center \\ 1805 Cambridge Street \\ Cambridge, MA 02138 \\ ponzetto@fas.harvard.edu
}




\section{Introduction}

The hypothesis that higher education leads to more democratic politics (Lipset 1959, 1960) has received a good deal of empirical support (Barro 1999, Glaeser et al. 2004, Papaioannou and Siourounis 2005). However, the theoretical reasons for this relationship remain unexplored. In this paper, we investigate both theoretically and empirically why stable democracies are so rare outside of countries with high levels of education.

Our starting point is the connection between education and political participation. This connection has been emphasized by Almond and Verba (1989, $1^{\text {st }}$ ed. 1963), who see education as a crucial determinant of “civic culture" and participation in democratic politics. “The uneducated man or the man with limited education is a different political actor from the man who has achieved a higher level of education (p. 315).” Almond and Verba's work has influenced both political science (e.g., Brady et al. 1995) and sociology (e.g., Kamens 1988), and our work can be seen as an elaboration of their ideas using theoretical and empirical tools of economics.

Perhaps the most dramatic place to see the effect of education on political participation is student activism. Students rioted against authority at Oxford, Bologna, and Paris even in the Middle Ages. Martin Luther found the most immediate intense support from the students in Wittenberg and other German universities. Students played key roles in liberal movements and revolutions in Europe in the middle of the $19^{\text {th }}$ century. "If the revolution had a core, it was the young educated elite” (Randers-Pehrson, 1999, p. 145). Both Engels and Lenin complained that students were unwilling to subject themselves to the leadership of the revolutionary - and not so democratic - elites. More recently, student demonstrations played a role in the overthrow of Peron in Argentina in 1955, the downfall of Perez Jimenez in Venezuela in 1958, the resistance to Diem in Vietnam in 1963, the resignation of the Kishi government in Japan in 1960, the anti- 
Sukarno movement in Indonesia in 1966, the downfall of Ayub Khan in Pakistan in 1969, the October demonstration in Poland in 1956, the Hungarian Revolution in 1956, the Prague Spring in 1968, and the toppling of the Rhee government in Korea in 1966. The Tiannamen student uprising of 1989 failed to depose the Communist Party, perhaps because the students got little support in generally uneducated China and were massacred by the troops. Most recently, peaceful demonstrations in which students played a key part helped save democracy in Ukraine against the aggrandizement by the ex-President who stole the election.

It would be incorrect to conclude from these examples that students have a preference for democratic government - perhaps because they value freedom, information, or elections -- rather than for political participation. The hep-hep anti-semitic riots in Bavaria in 1819 started when “during an academic ceremony an aged professor who had recently come out in favor of civic rights for Jews had to run for his life as angry students assaulted him.” Mussolini enjoyed substantial support from students in the young fascist movement. Hitler likewise relied on the Nazi students, who eventually seized control of the universities. In Latin America, students offered strong support to the Che Guevara led communist guerilla movement, no friends of democracy. The evidence that students organize to participate in collective action - democratic or anti-democratic -- is much more compelling than the evidence of their preference for democracy. Our goal, then, is to explore more deeply the consequences of what we take to be the primitive connection between education and participation.

In Section II, we present some old and some new facts about education and democracy. We show that more educated democracies are more stable than the less educated ones, that higher education predicts transition from dictatorship to democracy but not the other way around, 
and that the relationship between education and democracy holds within as well as across countries. The evidence suggests that, consistent with Lipset, education causes democracy.

In Section III, we motivate the basic assumption of our model, namely that education leads to higher participation in a whole range of social activities, including politics. Using micro-evidence from both the United States and other countries, we document the robust correlation between many forms of civic activity, including political participation, and education.

The correlation between education and civic activity is clear; the reasons for this correlation are less obvious. In one view, schooling incorporates indoctrination about the virtues of political participation. A second view holds that much of human capital is actually social capital and that schools teach students to interact with one another. Indeed, at least two of the three Rs (reading and writing) are skills for interpersonal communication. By improving interpersonal skills, education facilitates civic involvement. A third hypothesis sees the more educated as more effective at everything, including both work and civic activities, and therefore as likely to spend more time on both at the expense of leisure. We review these theories and assess them empirically in section III.

Motivated by this evidence, we present a model of regime stability in Section IV. We define democracies as regimes whose benefits are distributed among large numbers of citizens, and dictatorships as regimes whose beneficiaries are few in number. ${ }^{1}$ Dictatorships offer sharp incentives to their supporters because regime insiders earn large political rents. Democracies offer weaker incentives because the political rents are shared among many people. Our core

\footnotetext{
${ }^{1}$ Following the Oxford English Dictionary, we think of democracy as popular government or government by the people. Schumpeter (1942) defines democracy in terms of competition for votes, and that definition is accepted by Huntington (1991) and Posner (2003). Because we consider competition between democracies and dictatorships, for us the central difference is the distribution of political spoils in different regimes. Most precisely, democracy in our model is government for the people.
} 
assumption is that education raises the benefits of political participation. As a consequence, relatively more people fight for the more inclusive regimes as human capital increases.

In this model, the political success of a democracy hinges on having a large number of supporters whose benefits of political participation are sufficiently high that they fight for it despite the low personal incentives. Education supplies such supporters and stabilizes democracy. Conversely, in countries with low levels of education, dictatorship is more stable than democracy, because only dictatorships offer the strong incentives needed to induce people to defend them. In the model in Section IV, countries with higher levels of education are more likely both to experience a transition from dictatorship to democracy, and to withstand antidemocratic challenges. Moreover, the size of the most successful challenger regime to an existing dictatorship rises with the level of education.

In addition to having some empirical support for its core assumption and delivering the broad empirical predictions documented in Section II, the model has several new implications. It predicts that, it general, education causes the more inclusive groups to dominate politics. It also erodes the power of the incumbent, and can therefore lead to short run instability. In particular, as education increases, groups challenging to existing regimes become progressively larger -- small coups are replaced by large revolutions. Although they remain to be formally tested, these predictions are consistent with a broad outline of European transition to democracy.

\section{The Empirical Relationship between Education and Democracy}

Across the world, the correlation between education and democracy is extremely high. ${ }^{2}$

Figure 1 shows the relationship between the Polity IV index of democracy (Jaggers and Marshall

\footnotetext{
${ }^{2}$ Alvarez et al. (2000), Barro (1999), Boix and Stokes (2003), Glaeser et al. (2004), and Papaioannou and Siourounis (2005) also consider the relationship between income and democracy. The conclusion emerging from the
} 
2003) and the years of schooling in the country in 1960 (Barro and Lee 2001). Across 91 countries, the correlation coefficient between these variables is 74 percent.

In Table 1a-1c, we consider the effect of education on the stability of both democracies and dictatorships. For a country to be included in this sample, we require Barro and Lee's data on schooling in the initial year, as well as Jaggers and Marshall's (2003) continuous democracy classification since the initial year. For this table, we classify all countries with Polity IV ratings of or below 4 as dictatorships and those with ratings above 4 as democracies. The cutoff of four roughly corresponds to the sample median in 1960. Following Glaeser et al. (2004), we classify countries as well-educated if they have above 5.01 years of schooling in 1960 (the $75^{\text {th }}$ percentile in the sample schooling distribution in 1960), moderately educated if they have below 5.01 but above 2.68 years of schooling (the $50^{\text {th }}$ percentile of the sample schooling distribution in 1960), and low-educated if the 1960 years of schooling are below 2.68 years.

Table 1a covers the well-educated countries. In the first row, we count that 20 (out of 22) of these countries were democracies in 1960. The only two well-educated dictatorships were Hungary and Poland, which were non-democratic because of foreign occupation and whose people rebelled against the Soviet-backed dictatorships. Of the 20 well-educated democracies in 1960, every one except for Uruguay (one of the least educated countries in this group) remained democratic over the next 40 years. Both Poland and Hungary became democracies by 1990 .

The second row in Table 1a takes 1970 as the starting point and looks over the next 30 years. 22 out of 26 well educated countries were democracies in 1970, and four were dictatorships. In this year, Argentina and Greece join Hungary and Poland as well educated dictatorships. Of the 22 democracies, two lost this status by 2000. All four dictatorships circa

controversies is that income does cause transition to democracy, as well as its stability. Our focus, however, is on education not income. Nor do we consider the consequences of democracy, see, e.g., Przeworski and Limongi (1993) and Mulligan et al. (2004). 
1970 turned democratic by 1990 . The third row begins in 1980 . While there are 9 well-educated dictatorships in that year, all become democratic by 2000, and all 25 democracies stay democratic for the next 20 years. Starting in 1990, we again see the permanence of democracies, and the tendency of dictatorships to become democratic even within a decade. Averaging across the starting years 1960, 1970 and 1980, the probability of a well-educated democracy remaining a democracy twenty years later is 95 percent. The probability of a well-educated dictatorship becoming a democracy within 20 years is 87 percent.

In Table 1b, we turn to countries with moderate education. Three results are noteworthy. First, the probability of starting out as a democracy is much lower. Only 11 of 17 countries with this level of education are democracies in 1960, and only 7 out of 19 in 1970 . Second, the survival rate for democracies is lower. Averaged across the starting years 1960, 1970 and 1980, the probability of a moderately-educated democracy remaining a democracy twenty years later is down to 74 percent. Third, the likelihood that a dictatorship turns into a democracy is lower as well. Averaged over 1960, 1970, and 1980, the twenty year democratization rate is down to 54 percent from the 87 percent level for high-education countries.

In Table 1c, we examine countries with fewer than 2.7 years of education in the initial period. Democracies in this group are rare indeed. In 1960, there are only four poorly-educated democracies. Of these, only India (which is a striking outlier) and Venezuela survive over the next forty years, and Venezuela’s democracy score has been falling since 1990. In 1970, there are only three democracies with this little education. Only India survives over the next thirty years. In 1980, there are four democracies with less than 2.7 years of schooling. Two of those survive over twenty years. Finally, there are five democracies with less than 2.7 years of education in 1990, only two of which survive over ten years. Averaged across the starting years 
1960, 1970 and 1980, the probability of a low-educated democracy remaining one twenty years later is only 54 percent. We can make similar calculations for the democratization of loweducation dictatorships. Averaged over the starting years 1960, 1970, and 1980, the probability that such a dictatorship democratizes is 26 percent.

In sum, high-education democracies are more persistent than low-education ones, and high-education dictatorships are more likely to democratize than low-education ones. But is this relationship causal? Or is causality running from democracy to education? The evidence on transitions from dictatorship to democracy helps answer these questions. Figure 2 shows the raw correlation between the change in the Jaggers and Marshall (2003) democracy score and years of schooling in 1960 (from Barro and Lee) for countries that had low democracy ratings (zero or one) in 1960. This correlation is 66 percent. If we take the entire sample of countries and regress the change in democracy on initial democracy and initial years of education, we estimate:

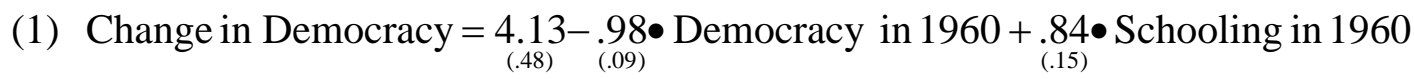

There are 65 observations in this regression and the R-squared is 67 percent. Initial schooling, even in highly dictatorial regimes, strongly predicts becoming more democratic over time. In contrast, democracy does not predict growth in schooling. We estimate:

(2) Change in Schooling $=\underset{(.28)}{2.80}+\underset{(.05)}{.07} \bullet$ Democracy in $1960-\underset{(.09)}{0.08} \bullet$ Schooling in 1960

There are 68 observations in this regression and the R-squared is only three percent. The relationship between initial democracy and changes in years of schooling is shown in Figure 3. While both in Table 1 and here the evidence suggests that schooling leads to democracy, there is no evidence that democracy leads to schooling. 
This evidence is subjected to more formal specifications by Glaeser et al. (2004) and Papaioannou and Siourounis (2005). Both studies confirm that education is a strong predictor of transition to democracy. The second study in particular focuses on the third wave of democratization (Huntington 1991) and shows that education is a powerful predictor of permanent transitions from dictatorship to democracy.

One objection to these findings is that some permanent country characteristics, such as geography or culture, are responsible for producing both education and democracy. In Table 2, we address this concern by estimating the relationship between education and democracy in regressions with country fixed effects:

(3) Democracy $_{i, t}=\alpha_{t}+\theta_{i}+\beta \bullet$ Schooling $_{i, t}+\varepsilon_{i, t}$,

where $\alpha_{t}$ represents a year fixed effect, $\theta_{i}$ is a country fixed effect and $\varepsilon_{i, t}$ is a country-year error term. Table 2 reports several specifications so that we can compare the results for both different data sets and different time periods. In all specifications, we use the Jaggers and Marshall (2003) democracy score.

The first column of Table 2 reports the results for the period 1960-2000, and uses Barro and Lee's schooling variable- the same period and the same data as we used in Table 1. With country and year fixed effects, the coefficient on schooling is no longer significant - indicating that a common cause explanation might indeed be valid. However, the Barro and Lee measure is well known for its extreme persistence. As documented in Glaeser et al. (2004), the correlation between Barro and Lee's measure of years of schooling in one year and the same measure ten years later is never less than 97 percent. This suggests that longer panels, new data, or both are needed to estimate any within-country relationship between education and democracy. 
Accordingly, in the rest of Table 2 we use Banks (2004) data on university and secondary school enrollments from 1865 to 2000 . The enrollments data are not nearly as persistent as the Barro and Lee measure, because conceptually they reflect investments in rather than stocks of human capital. The panel is unbalanced and over the entire time period we have 133 countries. We have data at five year intervals giving us 25 time periods and a total of 1316 observations.

In the second and third columns, we keep the time period 1960-2000, but include separately secondary school and university enrollment measures form Banks. Even for the short forty year interval, the effects of enrollments on democracy are now large and statistically significant in a country fixed effects specification. That is, within countries, educational investment predicts democracy. In the fourth and fifth specifications, we again use secondary school and university enrollment separately, but now use the whole time period from 1865 to 2000. The coefficients on education variables rise in magnitude and statistical significance. The coefficient of 0.290 on secondary school enrollment means that a ten percent increase in such enrollment is associated with a 2.90 point increase in the democracy score - a huge change. The coefficient of 0.850 on university enrollment implies that a one percent increase in such enrollment is associated with a 0.85 point increase in the democracy score. The sixth regression includes both secondary school and university enrollment together. In this specification, both coefficients fall, although that on university enrollment remains statistically significant.

The final specification does not include country fixed effects. Both coefficients more than double, reflecting the fact that the correlation between education and democracy is stronger across countries than within countries over time. This result is unsurprising, and could reflect an effect of school enrollment at a point in time on democracy in later time periods, both because people influence politics over their entire lives, and because educated people can create lasting 
political institutions. Still, despite these issues of timing, Table 2 shows a strong relationship between education and democracy within and not just across countries.

The bottom line of this section is strong support of Lipset’s (1960) hypothesis. Education is highly correlated with democracy in both cross-section and panel regressions with fixed effects. Moreover, the effect seems to be causal, as evidenced by the evidence on transition to democracy. The question now is what theory best explains these results.

\section{Education and Civic Participation}

Education may promote democracy because it raises the benefits (or reduces the costs) of political activity. In section IV, we take this as an assumption and show how it explains the evidence. In this section, we describe some theories of why education raises civic participation and then present some empirical evidence bearing on them.

\section{Why Should Education and Civic Participation Be Correlated?}

Perhaps the simplest hypothesis explaining the link between education and civic participation is that indoctrination about political participation is a major component of education. In democracies, schools teach their students that political participation is good. One “content standard" listed by the State of California's Department of Education aspires that students "understand the obligations of civic-mindedness, including voting, being informed on civic issues, volunteering and performing public service, and serving in the military or alternative service." The original public school movement in the United States emphasized preparing students for participation in democracy. This emphasis is not unique to America. Holmes (1979) synthesizes the aims of schools systems around the world. Political aims are often cited as an educational goal: "school work is organized so as to develop democracy in 
school and consequently in society as a whole" (Sweden), "the Constitution states that a general aim of education is to produce good citizens, a democratic way of living and human solidarity” (Costa Rica), and "an education system that creates knowledgeable, democratic and patriotic citizens is the aim of the Indonesian government." Perhaps the key implication of the indoctrination hypothesis is that the positive impact of schooling should be particularly pronounced in political rather than all social participation.

A second hypothesis holds that schooling lowers the costs of social interactions more generally. According to this view, a primary aim of education is socialization-teaching people how to interact successfully with others. Such successful interaction includes understanding and appreciating the others' point of view, as well as being able to effectively communicate one's own, through both writing and speech. When people communicate successfully, they may control any innate anti-social tendencies, and as a consequence become more productive participants in group activities (Bowles and Gintis, 1976). Formally, socialization can be thought of as raising the benefits of social engagement, or reducing the costs of such engagement, or increasing the productivity of working together in groups.

Education textbooks list socialization as a pillar of curriculum design. Driscoll and Nagel (2005) describe several curricular approaches to primary education. Many of these list social outcomes among the goals: "the children will develop cooperative relationships, reflecting both social skills and understanding the perspectives of others” (the Kamii and DeVries approach); "socialization of children. Self-regulation of behavior is necessary to participation in forms of society and in relationship with others" (the Bank Street approach); and "conditions that promote or strengthen relationship between children, and between children and adults" (the Waldorf approach). Gordon and Browne (2004) write that "a major role for the early childhood teacher is 
to see that children have enjoyable social contacts and to help motivate children toward a desire to be with others," because "enhancing social intelligence builds a set of skills that may be among the most essential for life success of many kinds.”

Why do schools spend so much effort on socializing children? An altruistic view might suggest that the ability to work well in social settings is among the most important skills needed to function in society. A more cynical view sees socialized children as easier for their teachers to manage. Whatever the reason, schools in all political and religious regimes devote considerable resources to teaching social cooperation ${ }^{3}$.

The socialization hypothesis predicts that education should impact all forms of social involvement. Its ability to predict political engagement should be no stronger than that for other forms of social participation. This theory also predicts no difference in the impact of education on social activities in democracies or non-democracies.

A third hypothesis holds that schooling raises political participation because it increases its personal material benefits. After all, the usual economist's interpretation of education is that it increases cognitive capabilities and effectiveness. The impact of education on competence should not be limited purely to the economic domain; more educated people are more likely to become political or civic leaders just as they are more likely to earn more money. Higher returns from civic activity for the more educated might explain a positive link between education and civic engagement.

The benefits hypothesis predicts that education should be most strongly associated with forms of civic engagement which yield private returns. Participation in lobbying groups or trade

\footnotetext{
${ }^{3}$ By social cooperation we do not mean obedience to authority. Obedience to authority is of course something different that schools also teach, although evidently not as successfully, as the evidence of student - and more generally educated people's - activism against authority illustrates.
} 
unions may be attractive because these groups serve the individual's interests. However, education is unlikely to raise the private returns to voting (or suicide bombing).

These three hypotheses all assume that education causes civic participation. It is at least possible that the link between schooling and education represents selection, not treatment, and that exogenous characteristics that make people tolerant of education also enable them to sit through meetings or wait in line to vote. If this were true, then exogenous increases in schooling would have no impact on overall levels of civic participation. Furthermore, if innate characteristics vary more within than across areas, this view predicts a low (or non-existent) relationship between education and civic participation at the aggregate level.

\section{Empirical Evidence on the Education and Civic Participation}

Using the World Values Survey (WVS), we begin with cross-country evidence on education and membership in social groups. We exclude countries with the Polity IV autocracy score above 5 from the analysis because these countries force party and other participation. (For example, 25\% of the Chinese respondents report membership in the Communist party). Figure 4 presents the results for the available 28 countries. It shows a sharply positive and statistically significant $(\mathrm{t}=2.49)$ relationship between education and participation in social groups. This evidence is broadly consistent with our theoretical perspective, but unfortunately does not allow us to distinguish the various hypotheses.

We can do that better with individual-level evidence from the United States. There are two primary individual-level sources for information on social activities: the General Social Survey (GSS) and the DDB Needham Lifestyles Survey. Using the GSS, DiPasquale and Glaeser (1999) document a strong positive relationship between education and a variety of social outcomes. College graduates are 27 percent more likely than high school dropouts to say that 
they vote in local elections and 29 percent more likely to say that they help solve local problems.

College graduates are also more likely to join organizations. Glaeser and Sacerdote (2001) show this to be true for fifteen out of sixteen forms of group membership: the exception is trade union membership. Using the WVS, they also find a significant positive relationship between years of education and group membership in almost every country. Education also positively predicts church attendance in the GSS. Fifty percent of American college graduates say that they attend church more than several times per year; thirty-six percent of high school graduates say they attend that often.

Using evidence from the DDB Needham Lifestyles Survey, we revisit some of those results in Table 3. The DDB Needham Survey is administered over the years 1975-1999 and covers (for many questions) a larger sample than the GSS. We control for basic demographics such as age, race and gender. All of our variables are categorical and take discrete values capturing the frequency of the activity. We normalize each of these variables to have a mean of zero and a standard deviation of one. We also control for income. Because (as in the GSS) income is missing for many observations, we include these observations but code them as having the mean value of income in the sample, and add a dummy which takes on a value of one when income is missing. We also include a dummy for each survey year to capture time trends in social activities. We measure education with two separate dummy variables. The first takes on a value of one if the person is a high school graduate and zero otherwise. The second variable takes on a value of one if the person is a college graduate and zero otherwise. Our results do not change if we use continuous measures of education.

In each regression, both education variables positively affect participation and both are almost always statistically significant. The first regression shows the impact of education on 
attending church. The effect of being a college graduate relative to a high school dropout is more than 30 percentage points. The second regression shows the large and positive impact of education on attending a class or a seminar.

Regression (3) shows a strong association between schooling and self-reported working on a community project. In the fourth regression, we look at writing a letter to a newspaper, a particularly clear form of civic engagement. Again, the correlation with education is positive, and the effect of college education is particularly strong. Since the mean of this variable is much lower than that of many others, we should not be surprised that the coefficients on schooling are smaller. Regression (5) shows results on contacting a public official. Again, the impact of education is strong.

Regression (6) looks at registering to vote. Obviously, this variable is an important measure of political participation in a democracy. Registering to vote (and voting) is particularly strongly associated with years of education. Finally, regression (7) shows that giving someone the finger-an anti-social form of behavior -- is negatively associated with years of schooling. These regressions show a pervasive pattern, in which years of schooling are associated not only with political participation in a democracy, but also with many other forms of social engagement.

Because our model addresses political battles that are often violent outside the U.S., we now turn to the evidence on more violent forms of group activity. Education and training are closely linked to military discipline and group coherence under fire (Hanson, 2002). Following Keegan (1976) and many others, Hanson argues both that historically military success is primarily the result of troops not fleeing under fire and that military discipline is itself the result of culture and education. Costa and Kahn (2003) show that illiteracy strongly predicts desertion among Union soldiers in the American Civil War. 
Ferguson (1999) looks at the ratio of prisoners of war to total casualties across countries during the First World War. This variable is described by some military historians as a measure of soldiers' willingness to surrender, as opposed to fight, under fire. Across major combatant countries, the ratio of prisoners to total casualties was the lowest for the United Kingdom, the United States, and Germany (1.4\%, 6.7\% and 9\% respectively). These arguably were the best educated combatants. The ratio of prisoners to total casualties was the highest among Russians, Austro-Hungarians and Italians (51.8\%, 31.8\% and 25.8\%) - the least educated of the major combatants. More standard forms of military history corroborate that these prisoner rates capture general failures of morale.

Perhaps more controversially, Krueger and Maleckova (2003) and Berrebi (2003) link education to terrorism in the Middle East. They argue that terrorists see their effort as pro-social and supportive of their community. Consistent with this argument, Krueger and Maleckova (2003) find that education predicts participation in Hezbollah activities in Lebanon. Berrebi (2003) shows that more educated Palestinians are more likely to be suicide bombers.

Finally, two recent studies address the view that the correlation between education and participation is selection. Millian, Moretti, and Oleopolos (2004) find that exogenous increases in education due to compulsory schooling laws raise voter turnout. Dee (2004) finds that increases in education accounted for by availability of junior and community colleges have a large effect on subsequent participation in voting. These results suggest that the effect of education on political participation is causal, rather than just the consequence of selection.

Can the evidence help us distinguish between the other hypotheses? The fact that education predicts such social behavior as voting and fighting rather than surrendering, which do not earn private rewards, is inconsistent with the private benefits hypothesis. The fact that 
education increases all forms of participation, many of which are deeply apolitical, goes against the political indoctrination hypothesis. That hypothesis is also undermined by the peaceful anticommunist revolutions throughout Eastern Europe and the former Soviet Union, dominated by educated people with years of pro-communist indoctrination under their belts. Given the separation between church and state in the U.S. and U.K., and given the often anti-religious sentiment of the French educational establishment, the positive correlation between years of education and church attendance is hard to understand as reflecting political indoctrination.

The theory that best explains all of the facts is the second hypothesis: education is socialization. This theory predicts the universal relationship between education and participation across activities and across countries. Of course, this does not mean that other mechanisms do not also operate, but we are inclined to accept the view that acquiring social capital is a crucial part of acquiring human capital.

\section{A Model of Education and Democracy}

In this section, we model a channel through which education encourages democracy, both by increasing its stability and by increasing the probability of transition to democracy. The critical assumption, following the evidence of the previous section, is that education raises the benefits of political participation. The core insight of the model is that democracy requires support from a broad base of citizens who face only weak incentives to fight for it, while dictatorships offer strong incentives to a narrow base of supporters. Education raises the benefits of political participation and draws relatively more people to support democracy even when they face only weak incentives. 


\section{Model Setup}

We assume that the country is populated by measure 1 of homogeneous citizens, each with a human capital level of $h \geq 0 .^{4}$ A regime is defined as a set $G$ of insiders, with $g \in[0,1]$ being the measure of the set, or the size of the regime. We interpret a larger $g$ as a more democratic regime. We call a regime with $g=1$ a perfect democracy.

In period zero, there is an exogenous status quo regime $G_{0}$ of size $g_{0}$. In period one, an alternative regime, $G_{1}$ of size $g_{1}$, is proposed ${ }^{5}$. Membership in each regime is exogenous. In period two, individuals choose whether to defend the existing regime, to fight for the new regime, or to stay politically uninvolved. Individuals may not support both regimes. Thus, in this model, while each individual takes as given his membership in a particular regime (or in neither), he still chooses whether to participate in politics.

We let $s_{0}$ denote the endogenously determined measure of people who support $G_{0}$ and $s_{1}$ denote the measure of people who support $G_{1}$. The challenger unseats the incumbent if and only if $\varepsilon_{0} s_{0} \leq \varepsilon_{1} s_{1}$, where $\varepsilon_{i}$ are random shocks to the effectiveness of each faction's supporters.

The ratio $\rho \equiv \frac{\varepsilon_{0}}{\varepsilon_{1}}$ has a continuous probability distribution $Z(\rho)$ on $\mathbb{R}^{+} .6$

\footnotetext{
${ }^{4}$ In Bourguignon and Verdier (2000), as in our model, political participation depends on education, but education is determined by the initial income distribution.

${ }^{5}$ In our model, what matters is the relative and not the absolute size of the two regimes. As a consequence, unlike in some other models of policy choice (e.g., Mullainathan and Shleifer 2005), raw population does not affect the likelihood of democracy. Campante and Do (2005) present a model in which the raw population influences the availability of recruits for the anti-dictatorial coup, and hence the likelihood of democracy.

${ }^{6}$ In particular, if $\zeta$ is the density of $\varepsilon_{i}$ it is straightforward to compute the distribution

$Z(\rho)=\int_{0}^{\infty} \int_{0}^{\rho \varepsilon_{1}} \zeta\left(\varepsilon_{1}\right) \zeta\left(\varepsilon_{0}\right) d \varepsilon_{0} d \varepsilon_{1}$ and its density $z(\rho)=\int_{0}^{\infty} \zeta(\rho \varepsilon) \zeta(\varepsilon) d \varepsilon$.
} 
Each decision-maker is of measure zero and so does not impact the probability that either regime succeeds. Individuals therefore do not base their political participation decisions on their impact on the outcome. Instead, participation is based on three different forces. First, regimes provide incentives to their members to participate. We assume that these incentives take the form of punishing a regime's insiders who do not fight for it. Second, regime insiders who participate themselves motivate their fellow insiders to join them. We model this as a benefit from participation. We also assume that there are individual-specific costs of participation.

We formally model a regime's power to motivate insiders by assuming that insiders who fail to support their regime suffer an expected utility loss equal to $p(g)$. We assume that $p$ is a monotone decreasing function of $g$, ranging from $p(0)=\bar{p}$ to $p(1)=\underline{p} \geq 0$. Smaller groups impose larger punishments on free-riders. This assumption follows Mancur Olson's hypothesis that smaller groups are better at solving free-rider problems: "the greater effectiveness of relatively small groups $[\ldots]$ is evident from observation and experience as well as from theory” (Olson 1965, p. 53). Smaller groups benefit from mutual monitoring and punishment of transgressors. As Olson (p. 61) writes, "In general, social pressure and social incentives operate only in groups of smaller size.” This assumption sets up the basic tradeoff between smaller and larger regimes. Small regimes provide strong incentives to a small base. Larger regimes provide much weaker incentives but to a larger potential base of supporters.

We allow for the possibility that the incumbent regime can have an advantage in eliciting support, which is modeled by assuming that insiders in an incumbent regime who fail to support it pay an additional expected utility cost of $a \geq 0$. This incumbent advantage may simply reflect access to the machinery of the state. 
The threat of punishment captures the global incentives provided by the leaders to all insiders. We also allow regime insiders who participate to motivate their peers to do likewise. While the regime level motivation should be thought of as leaders threatening members, we think of this local motivation as friends convincing friends to come out and fight. Precisely because of their local nature, these benefits are independent of the aggregate size of the regime. In line with Section III, we assume that they are a function of the human capital of regime members. These local incentives are represented by a function $b(h)$ that is monotonically increasing in $h$, ranging from $b(0)=\underline{b}$ to $\lim _{h \rightarrow \infty} b(h)=\bar{b}$. Higher levels of human capital make people better at inducing their peers to politically participate.

The function $b(h)$ captures the role of education in creating social skills, in two different ways. First, more educated people are better at cajoling, encouraging, motivating, or otherwise persuading others they interact with to join them. Second, more educated people are better able to reap the benefits of social interaction themselves, perhaps because they understand better why they are participating. Socialization covers the twin powers to persuade and to understand, both captured by $b(h)$. It is more appealing to participate in a collective activity the more educated a person is, and the more educated the other participants are.

Offsetting the global and local incentives is an effort cost of political participation, which equals $c+\eta$, where $c>0$ is the average cost and $\eta$ a mean-zero idiosyncratic shock which is identically and independently distributed across all individuals. This shock is realized at the start of period two, after membership in the two regimes has been defined. We make two technical assumptions on the distribution of cost shocks: (1) the distribution function $F(\eta)$ is log-concave, and (2) $\eta$ has support $\lfloor\underline{\eta}, \bar{\eta}\rfloor$ such that $\underline{\eta} \leq \underline{p}+\underline{b}-c<\bar{p}+\bar{b}-c \leq \bar{\eta}$. The first assumption 
implies that $\frac{f(\eta)}{F(\eta)}$ is monotonically decreasing in $\eta$. Economically, this assumption means that the more supporters a regime already has, the more expensive it becomes for it to attract additional supporters. The cost of providing incentives for turnout is convex. This assumption is “commonly made in the incentives literature and is satisfied by many distributions” (Laffont and Tirole 1988, p. 1157). Bagnoli and Bergstrom (1989) show that this assumption is satisfied by the uniform, normal, lognormal, exponential, Pareto, logistic, gamma, chi-square, extreme-value, power-function, Weibull and Laplace distributions, and by any truncation thereof.

The second assumption is simplifying, and implies that among individuals belonging to one and only one regime there are always some supporting the regime and some choosing not to participate, regardless of regime size and human capital. This assumption enables us to avoid the uninteresting case where there is no margin of participation in a regime.

\section{Human capital and political competition}

Consider a contest between two exogenously formed regimes $G_{0}$ and $G_{1}$. Individuals excluded from both regimes abstain from political participation as they reap no benefits and only incur costs. Members of $G_{0}$ and not $G_{1}$, whose mass is denoted by $\hat{g}_{0}$, have two options: abstaining, which has a cost $p\left(g_{0}\right)+a$, or participating in support of $G_{0}$, which has a cost $c+\eta-$ $b(h)$. Likewise, members of $G_{1}$ and not $G_{0}$, whose mass is denoted by $\hat{g}_{1}$, can abstain at a cost $p\left(g_{1}\right)$ or support $G_{1}$ at a cost $c+\eta-b(h)$. Finally, some individuals could belong to both regimes: they can then choose to abstain at a cost $p\left(g_{0}\right)+p\left(g_{1}\right)+a$, to support $G_{0}$ at a cost $p\left(g_{1}\right)+c+\eta-b(h)$, or to support $G_{1}$ at a cost $p\left(g_{0}\right)+a+c+\eta-b(h)$. 
It is immediate that if $g_{1}>g_{0}$, no incumbent can be induced to switch allegiance: conditional on participation, he always prefers to fight for the current regime both because it is smaller and because of the incumbency advantage. More generally, politically active members of both regimes support the incumbent if and only if $a>p\left(g_{1}\right)-p\left(g_{0}\right)$.

We can now compute support levels for the two regimes. If $a>p\left(g_{1}\right)-p\left(g_{0}\right)$, then total support for the incumbent is $g_{0} F\left(p\left(g_{0}\right)+a+b(h)-c\right)$, and that for the challenger $\hat{g}_{1} F\left(p\left(g_{1}\right)+b(h)-c\right)$. If $g_{1}<g_{0}$ and $0 \leq a \leq p\left(g_{1}\right)-p\left(g_{0}\right)$, then total support for the incumbent is $\hat{g}_{0} F\left(p\left(g_{0}\right)+a+b(h)-c\right)$ and that for the challenger $g_{1} F\left(p\left(g_{1}\right)+b(h)-c\right)$. Putting these two pieces together, the probability that the challenger $G_{1}$ replaces the incumbent $G_{0}$ equals

$$
\pi=\left\{\begin{array}{lc}
Z\left(\frac{g_{1} F\left(p\left(g_{1}\right)+b(h)-c\right)}{\hat{g}_{0} F\left(p\left(g_{0}\right)+a+b(h)-c\right)}\right) & 0 \leq a \leq p\left(g_{1}\right)-p\left(g_{0}\right) \\
Z\left(\frac{\hat{g}_{1} F\left(p\left(g_{1}\right)+b(h)-c\right)}{g_{0} F\left(p\left(g_{0}\right)+a+b(h)-c\right)}\right) & a>\max \left\{0, p\left(g_{1}\right)-p\left(g_{0}\right)\right\}
\end{array}\right.
$$

Differentiation then yields:

Proposition 1: Consider a contest between two given regimes $G_{0}$ and $G_{1}$ :

(a) If $g_{1}>g_{0}$, or $g_{1}<g_{0}$ and $0 \leq a \leq p\left(g_{1}\right)-p\left(g_{0}\right)$, the probability that the more inclusive regime succeeds is increasing in the level of human capital.

(b) If $g_{1}<g_{0}$, or $a>p\left(g_{1}\right)-p\left(g_{0}\right) \geq 0$, the probability that the less inclusive challenger succeeds is increasing in the level of human capital. 
The mechanism underpinning part (a) of Proposition 1 can be easily grasped graphically. The area of each bar in Figure 5 represents the total support for one regime at two levels of $h$, with higher support resulting from higher human capital. The bar with the broader base captures the support for the democracy and the bar with the narrower base that for dictatorship. As education rises, both regimes receive more support, but because the democratic regime has by definition a broader base, the increase in raw numbers is higher for that regime.

Dictatorial regimes provide strong incentives for a favored few; democratic regimes with many insiders provide weak incentives for their potential supporters. The larger group has a wider base of supporters, but a lower participation rate. Higher levels of human capital favor democratic regimes because they increase the benefits of participation for everyone, and encourage a larger fraction of the many beneficiaries of a democracy to support it against a more dictatorial alternative. In the case presented in Figure 5, $\eta$ is uniformly distributed, so that the increase in the participation rate is identical for both groups regardless of their size. It is then immediate that the larger group derives a higher increase in its total support. More generally, the assumption that $F(\eta)$ is log-concave ensures that, for a given rise in $h$, the proportional increase in the participation rate is always at least as great for the smaller as for the larger group.

Figure 6 presents the relationship between human capital and the probability that a regime $G_{0}$ is replaced by a larger, non-overlapping regime $G_{1}$ for the case where $\varepsilon$ is lognormally distributed, $\eta$ is uniformly distributed, and specifications of $p$ and $b$ are consistent with our assumptions. In particular, the graph considers two challengers to a regime of size $g_{0}=15 \%$ : the flatter curve represents a challenge by the marginally larger oligarchy $g_{1}=20 \%$, while the more concave curve one by the almost democratic complement regime, $g_{1}=85 \%$. 
When education is low, a challenge by a rival oligarchy is much more likely to be successful. As education increases, the threat coming from a democratic uprising eventually becomes dominant.

Part (b) of Proposition 1 shows that with a sufficiently large incumbency advantage, education need no longer help the more inclusive regime, because education makes incumbency less valuable. The assumption that $\frac{f(\eta)}{F(\eta)}$ is monotonically decreasing in $\eta$ means that increasing education always helps the group with weaker initial incentives to participate. With an incumbency advantage $a>p\left(g_{1}\right)-p\left(g_{0}\right) \geq 0$, the larger incumbent offers stronger incentives even if $g_{1}<g_{0}$. In this case, therefore, an increase in education helps the challenging regime. When the challenger regime is larger than the incumbent, it offers weaker incentives both because of its size and because it lacks the incumbency advantage, and as a consequence education always helps it.

This part of the proposition suggests that education can create instability among competing dictatorships of roughly the same size. When people are uneducated, even a small incumbency advantage ensures that the ancien regime continues to win out. As education rises and there are more potential participants, the probability of success for another dictatorial challenger increases.

If we focus on perfect democracy, with $g_{1}=1$, it is immediate that a democratic challenge to a dictatorial regime always falls under part (a) of the proposition. The probability that democracy succeeds in replacing oligarchy is then increasing in the level of human capital.

In the opposite case, an oligarchic coup by a group $G_{1}$ such that $g_{1}<1$, attempts to overturn a perfect democracy $G_{0}$, for which $g_{0}=1$. This case is central to the stability of democratic regimes and is meant to shed light on subversions of initially democratic regimes by 
coups perpetrated by either outsiders or government insiders. It is important to note, first, that the coup is abortive if $a>p\left(g_{1}\right)-\underline{p}$, for then none of the prospective oligarchs switch allegiance from democracy to the challenging regime. As a consequence, democracy is perfectly stable if the incumbency advantage is sufficiently high, namely if $a>\bar{p}-\underline{p}$. If the coup has any probability of success, then we must once again be in the region described by part (a) of the proposition, and the probability that the coup succeeds in upending democracy is decreasing in the level of human capital. As before, as education rises, more people are willing to support democracy despite the weaker incentives it offers.

\section{Endogenous Regime Size and the Stability of Regimes}

We have shown that, among two rival regimes of exogenous sizes, an increase in human capital makes it more likely that the more inclusive one prevails. In particular, democracy is more likely to be instituted and preserved. We next address the possible endogeneity of regime sizes by asking which regime size maximizes the probability of a successful revolution. We do not formally model the decision-making process of regime-builders, but rather assume that the success-maximizing size is favored.

We now assume that $\eta$ is uniformly distributed on $[-\bar{\eta}, \bar{\eta}]$ with $\bar{\eta} \geq \max \{c-\underline{p}-\underline{b}, \bar{p}+\bar{b}-c\}$. We also assume that $p$ is three times continuously differentiable, and that $p^{\prime \prime \prime}>0$, which makes it possible for the cost of abstention to be first a concave and then a convex function of group size. Figure 7 shows an example of $p$ used in our simulations.

We start by analyzing a contest between competing oligarchies. To simplify the analysis, we assume that the challenger cannot recruit members of the incumbent oligarchy, or 
analogously that it is counterproductive to do so due to a sufficiently large incumbency advantage $a>\bar{p}-p\left(g_{0}\right)$.

For a fixed incumbent regime, $G_{0}$, the support of the non-overlapping challenger $G_{1}$ is equal to $s\left(g_{1}\right)=g_{1} \frac{p\left(g_{1}\right)+b(h)-c+\bar{\eta}}{2 \bar{\eta}}$. Increasing the size of a group has two opposing effects on its support: broadening the base and decreasing the incentives for that base to participate. The assumptions on $p$ imply that the function is initially increasing in $g_{1}$ and if $p^{\prime}\left(g_{1}\right)$ is sufficiently negative, the function eventually decreases. Assuming that, for sufficiently low levels of human capital $\mathrm{h} \simeq 0$, the size $g_{1}^{*}$ of the challenging regime that maximizes its support is interior, it follows that: ${ }^{7}$

Proposition 2: The size $g_{1}^{*}$ of the non-overlapping challenging regime that is most likely to overthrow a dictatorship $G_{0}$ is increasing in the level of human capital $h$, and may jump discretely to $\left(1-g_{0}\right)$ when $h$ crosses a threshold $\hat{h}$.

As human capital increases, the greatest threat to a dictatorship becomes an ever more democratic regime. For a sufficiently high level of human capital, the most successful revolution includes all but the members of the previous regime. A surprising element in this proposition is the jump. Figure 8 shows a possible graph of the support for a challenger to a dictatorship with

\footnotetext{
${ }^{7}$ This requirement is equivalent to the formal condition that $\exists \hat{g}_{1} \in\left(0,1-g_{0}\right): \hat{g}_{1}\left[p\left(\hat{g}_{1}\right)+\underline{b}-c+\bar{\eta}\right]>\left(1-g_{0}\right)\left[p\left(1-g_{0}\right)+\underline{b}-c+\bar{\eta}\right]$, failing which the supportmaximizing size of the challenger would be $g_{1}^{*}=1-g_{0} \forall h \geq 0$; the latter case remains in fact mathematically consistent with Proposition 2, but becomes economically uninteresting.
} 
$g_{0}=15 \%$; higher curves are associated with higher levels of $h$. In this case, there is indeed a discrete jump to the corner solution as human capital increases above $\hat{h}$, as shown in Figure 9.

The intuition for the jump in the size of the support-maximizing regime comes from the basic economics of regime size. For low levels of $g_{1}$, support increases with regime size. As size continues to grow, incentives rapidly decrease, which echoes the transition from a "small” to a "large” regime in Olson’s analysis. In this intermediate range, support decreases with regime size. As $g_{1}$ rises even further, $p\left(g_{1}\right)$ asymptotes towards its lower bound, and incentives are so low already that the marginal dilution is more than offset by the addition of new members. In this region, support is again increasing in regime size.

We now turn to the conspiracy $G_{1}$ that is most likely to overthrow a perfect democracy. This conspiracy sets $g_{1}$ to maximize $t\left(g_{1}\right)=\frac{s\left(g_{1}\right)}{1-g_{1}}$. The value of $\bar{g}_{1}$ for which $p\left(\bar{g}_{1}\right)=\underline{p}+a$ describes the maximum size of a conspiracy that provides sufficient incentives to attract traitors from a perfect democracy. Assuming that for sufficiently low levels of human capital $h \simeq 0$ the size $g_{1}^{*}$ of $G_{1}$ that maximizes its probability of success is interior, it follows that: ${ }^{8}$

Proposition 3: The size $g_{1}^{*}$ of the challenging regime that is most likely to overthrow a perfect democracy is increasing in the level of human capital $h$, and may jump discretely to $\bar{g}_{1}$ when $h$ crosses a threshold $\hat{h}$.

\footnotetext{
${ }^{8}$ This requirement is equivalent to the formal condition that $\exists \hat{g}_{1} \in\left(0, \bar{g}_{1}\right): \frac{\hat{g}_{1}}{1-\hat{g}_{1}}\left[p\left(\hat{g}_{1}\right)+\underline{b}-c+\bar{\eta}\right]>\frac{\bar{g}_{1}}{1-\bar{g}_{1}}\left[p\left(\bar{g}_{1}\right)+\underline{b}-c+\bar{\eta}\right]$, failing which the supportmaximizing size of the challenger would be $g_{1}^{*}=\bar{g}_{1} \forall h \geq 0$; the latter case remains in fact mathematically consistent with Proposition 3, but becomes economically uninteresting.
} 
Figure 10 graphs $t\left(g_{1}\right)$ with $\bar{g}_{1}=25 \%$; higher curves are associated with higher levels of $h$. Again, there is a discrete jump from an interior optimum to $g_{1}^{*}=\bar{g}_{1}$. Figures 11 and 12 respectively plot the maximum probability of a successful coup against democracy, and the size of the associated conspiracy, as a function of $h$.

This discussion suggests that the size of the success-maximizing challenger regimes increases with the level of education. At low levels of education, status quo dictatorships are most effectively challenged by small coups, often including bands of disgruntled opponents (Huntington 1957, Finer 1988, Campante and Do, 2005). At higher levels of education, the sizes of optimal uprisings against both dictatorship and democracy rise. In Europe during the age of Revolutions, increasingly large groups fought to overthrow the existing regime. Similarly, revolts against democracy, such as the Fascist takeover in Italy in the 1920s or the Nazi movement in Germany became increasingly broad-based in societies with more education.

\section{Implications}

The model provides one explanation for the empirical link between education and democracy, but also a further set of testable implications. Proposition 1 yields two predictions. First, the ability of a minority to withstand or displace a large popular movement declines with the education of the population. Second, the value of incumbency declines as education rises. Some anecdotal evidence seems consistent with these propositions.

Before 1600, European monarchies were relatively secure against broad-based uprising. Sporadic peasant revolts were generally crushed, and the real threat to a monarch usually came from a close relative offering an alternative monarchy. Starting with the Dutch revolution against Spain and the English revolution, monarchs were increasingly threatened by more 
broadly-based opposition groups. Notably, these two nations had unusually high levels of education. In the late 18th and 19th centuries, France, Germany and Italy all experienced popular uprisings as well, with large roles played by the more educated citizens. By 1920, monarchies had almost vanished in Europe, as the incumbency advantages of monarchs were wiped out in the aftermath of World War I. But it took another 25 years in Western Europe and another 70 years in Eastern Europe for democracy to become entrenched.

The implication of Proposition 1 for political instability also receives some support. England was unstable until 1689, with often violent royal successions (DeLong and Shleifer 1993). Four French regimes were toppled by popular revolts between 1789 and 1871, as the levels of education were growing. Similar instability was seen in Germany and elsewhere in the educated Europe. Once the transitions to democracy occurred, well educated democracies were themselves initially unstable. At least at first glance, one sees similar patterns of instability of democracy in Latin America, former Soviet Union, and other parts of the world.

Education also seems linked to the ability of democracies to defend themselves from dictatorial coups. Popular uprisings during the less educated periods (England 1640, France 1689, Russia 1917 and Germany in 1920) were almost invariably followed by dictatorial takeovers. The educated supporters of democracy tried but failed to resist the dictators. As nations became more educated, they also became more successful at defending democracy. In France in the 1870s and 1880s, the Third Republic faced risks from both the monarchists and the popular generals, like Boulanger. However, unlike the coups of 1797 and 1851, when the two Napoleons crushed their less organized opponents, in this later period a coalition of educated democrats protected the republic. Such a defense of democracy was even more striking in 1990, when educated Russians engaged in a remarkable campaign to stop an attempted putch. 
Propositions 2 and 3 suggests that education increases the optimal size of effective uprisings. This again seems supported by European and Latin American history. In less educated times and places, coups are generally small affairs including only small cadres of nobles or army officers (Campante and Do 2005). As education grows, effective uprisings (like the American Revolution) became larger. Eventually, large swaths of society were included in attempts to overthrow a regime. Even the Nazi takeover in Germany, which eventually led to a dictatorship, succeeded only after the Nazis had built a broad coalition, including students and other educated Germans. Their earlier attempt at a narrow coup proved an embarrassing failure.

\section{Conclusion}

The correlation between education and democracy is clear. The reason for this correlation is not. In this paper, we offer an explanation for the correlation.

Our explanation hinges on the connection between education and the costs and benefits of political engagement. Schools socialize young people and political involvement is one form of socialization; a variety of evidence shows a positive connection between education and civic engagement. We model education as raising the benefits of political action when individuals choose to support a more or less democratic regime. In this model, democratic regimes offer weak incentives to a wide base of potential supporters, while dictatorships offer strong incentives

to a narrower base. Education increases the society-wide support for democracy because democracy relies on people with high participation benefits for its support. We show that better educated nations are more likely both to preserve democracy and to protect it from coups.

The analysis raises two broader questions that are worth mentioning in conclusion. First, while our model has focused on the effects of education on participation, the analysis applies to 
all social glue that encourages collective action. For example, the analysis might suggest that ethnic homogeneity is good for democracy (although in cross-country or panel regressions with education controls, ethnic heterogeneity does not matter for democracy). This surely seems plausible, and remains to be explored. Perhaps as interestingly, the analysis suggests a solution of Olson's free-rider problem in all organizations, and not just in political regimes, namely human capital or other social glue as a motivation to participate.

Second, our analysis runs into the old puzzle, namely why do some dictators invest in education if they know that doing so eventually dooms them? The examples of fallen dictators in East Asia, Eastern Europe, and the former Soviet Union are telling reminders of this risk. There are several possible answers. One is that many dictators face an external threat, and therefore must grow their economies and their armies (including investing in human capital) to counter these threats even if this raises the risk of democratization. A second is that even selfish dictators unconcerned with external threats might derive income from economic growth, and therefore promote education to get richer. A third (and most original) idea is that all dictators face significant ouster risks, and that it is much better for the dictator's life for him to be replaced by a democracy in an educated country than by another dictator in an uneducated one.

Our initial empirical results offer scant hope for the success of democracies transplanted in highly uneducated countries. Among the countries for which we have data, only four with education levels like those of Afghanistan and Haiti have had democracies for twenty years of more (Botswana, India, Papua New Guinea and Venezuela). We estimate that the probability that democracies imposed on these countries will turn into dictatorships within 20 years is over 50 percent. As Iraq is better educated, the chance of democracy surviving is higher. Still, the odds are far from one. 


\section{References}

Almond, Gabriel, and Sidney Verba (1989, $1^{\text {st }}$ ed. 1963), The Civic Culture: Political Attitudes and Democracy in Five Nations, London: Sage Publications.

Alvarez, Michael et al. (2000), Democracy and Development: Political Institutions and Material Well-being in the World, 1950-1990. Cambridge: Cambridge University Press.

Bagnoli, Mark, and Theodore Bergstrom (1989), "Log-Concave Probability and its Applications,” Mimeo, University of Michigan.

Barro, Robert (1999), “Determinants of Democracy,” Journal of Political Economy 107: 158183.

Barro, Robert, and J.-W. Lee (2001), “International Data on Educational Attainment: Updates and Implications,” Oxford Economic Papers 53: 541-563.

Berrebi, Claude (2003), “Evidence About the Link between Education, Poverty, and Terrorism among Palestinians,” Mimeo Princeton University.

Boix, Carles, and Susan Stokes (2003), “Endogenous Democratization,” World Politics 55: 517549.

Bourguignon, Francois, and Thierry Verdier (2000), “Oligarchy, Democracy, Inequality, and Growth,” Journal of Development Economics 62: 285-313.

Bowles, Samuel, and Herbert Gintis (1975), Schooling in Capitalist America: Educational Reform and the Contradictions of Capitalist Life. New York: Basic Books.

Brady, Henry, Sidney Verba, and Kay Lehman Schlozman (1995), “Beyond SES: A Resource Model of Political Participation,” American Political Science Review 89: 271-294.

Campante, Filipe, and Quoc-Anh Do (2005), “Inequality, Redistribution, and Population,” Mimeo, Harvard University. 
Costa, Dora, and Matthew Kahn (2003), “Cowards and Heroes: Group Loyalty in the American Civil War,” Quarterly Journal of Economics 118: 519-548.

De Long, Bradford, and Andrei Shleifer (1993), “Princes and Merchants: European City Growth Before the Industrial Revolution,” Journal of Law and Economics 36, 671-702.

Dee, Thomas (2004), “Are there Civic Returns to Education?” Journal of Public Economics 88, 1697-1720.

DiPasquale, Denise and Edward Glaeser (1999), “Incentive and Social Capital: Are Homeowners Better Citizens?” Journal of Urban Economics 45: 354-384.

Driscoll, Amy and Nancy G. Nagel (2005), Early Childhood Education Birth -8: The World of Children, Families and Educators. Third Edition. Boston: Pearson Education.

Ferguson, Niall (1999), The Pity of War. New York: Basic Books.

Finer, Samuel (1988), The Man on Horseback: The Role of the Military in Politics. Boulder, Colorado: Westview Press.

Glaeser, Edward, and Bruce Sacerdote (2001), “Education and Religion,” NBER Working Paper. Glaeser, Edward, LaPorta, Rafael, Lopes-de-Silanes, Florencio, and Andrei Shleifer (2004), “Do Institutions Cause Growth?” Journal of Economic Growth 9: 271-303.

Gordon, Ann, and Kathryn Browne (2004), Beginnings and Beyond: Foundations in Early Childhood Education. Sixth Edition. Thomson Delmar Learning: Clifton Park, NY.

Hanson, Victor (2001), Culture and Carnage: Landmark Battles in the Rise of Western Power. New York: Doubleday.

Holmes, Brian (1979), International Guide to Education Systems. Paris: UNESCO. Huntington, Samuel (1957), The Soldier and the State: The Theory of Politics of Civil-Military Relations. Cambridge, Massachusetts: Harvard University Press. 
Huntington, Samuel (1991), The Third Wave: Democratization in the Late Twentieth Century. Norman and London: University of Oklahoma Press.

Jaggers, Keith, and Monty Marshall (2003), Polity IV Project, Center for International Development and Conflict Management, University of Maryland.

Kamens, David (1988), "Education and Democracy: A Comparative Institutional Analysis,” Sociology of Education 61: 114-127.

Keegan, John (1976), The Face of Battle. New York: Viking Press.

Krueger, Alan, and Jitka Maleckova (2003), "Education, Poverty, and Terrorism: Is there a Causal Connection?,” Journal of Economic Perspectives 17: 119-144.

Laffont, Jean-Jacques, and Jean Tirole (1988), “The Dynamics of Incentive Contracts," Econometrica 56: 1153-1175.

Lipset, Seymour Martin (1959), “Some Social Requisites for Democracy: Economic Development and Political Legitimacy,” American Political Science Review 53: 69-105. Lipset, Seymour Martin (1960), Political Man: the Social Basis of Modern Politics, New York: Doubleday.

Milligan, Kevin, Moretti, Enrico, and Philip Oreopoulous (2004), "Does Education Improve Citizenship? Evidence from the U.S. and the U.K.,” Journal of Public Economics 88: 16671695.

Mulligan, Casey, Ricard Gil, and Xavier Sala-i-Martin (2004), “Do Democracies Have Different Public Policies than Non-democracies,” Journal of Economic Perspectives 18, 51-74. Mulligan, Casey, and Andrei Shleifer (2005), "The Extent of the Market and the Supply of Regulation,” Quarterly Journal of Economics 120:1445-1473. 
Olson, Mancur (1965), The Logic of Collective Action: Public Goods and the Theory of Groups, Cambridge, Massachusetts: Harvard University Press.

Papaioannou, Elias, and Gregorios Siourounis (2005), "Economic and Social Factors Driving the Third Wave of Democratization,” Mimeo, London Business School.

Posner, Richard (2003), Law, Pragmatism, and Democracy, Cambridge, Massachusetts: Harvard University Press.

Przeworski, Adam, and Fernando Limongi (1993), "Political Regimes and Economic Growth,” Journal of Economic Perspectives 7: 51-70.

Rander-Pehrson, Justine Davis (1999), Germany and the Revolution of 1848-1849, New York: Peter Lang.

Schumpeter, Joseph (1942), Capitalism, Socialism, and Democracy, New York: Harper and Row.

Tilly, Charles, Louise Tilly, and Richard Tilly (1975), The Rebellious Century 1830-1930. Cambridge, Massachusetts: Harvard University Press. 


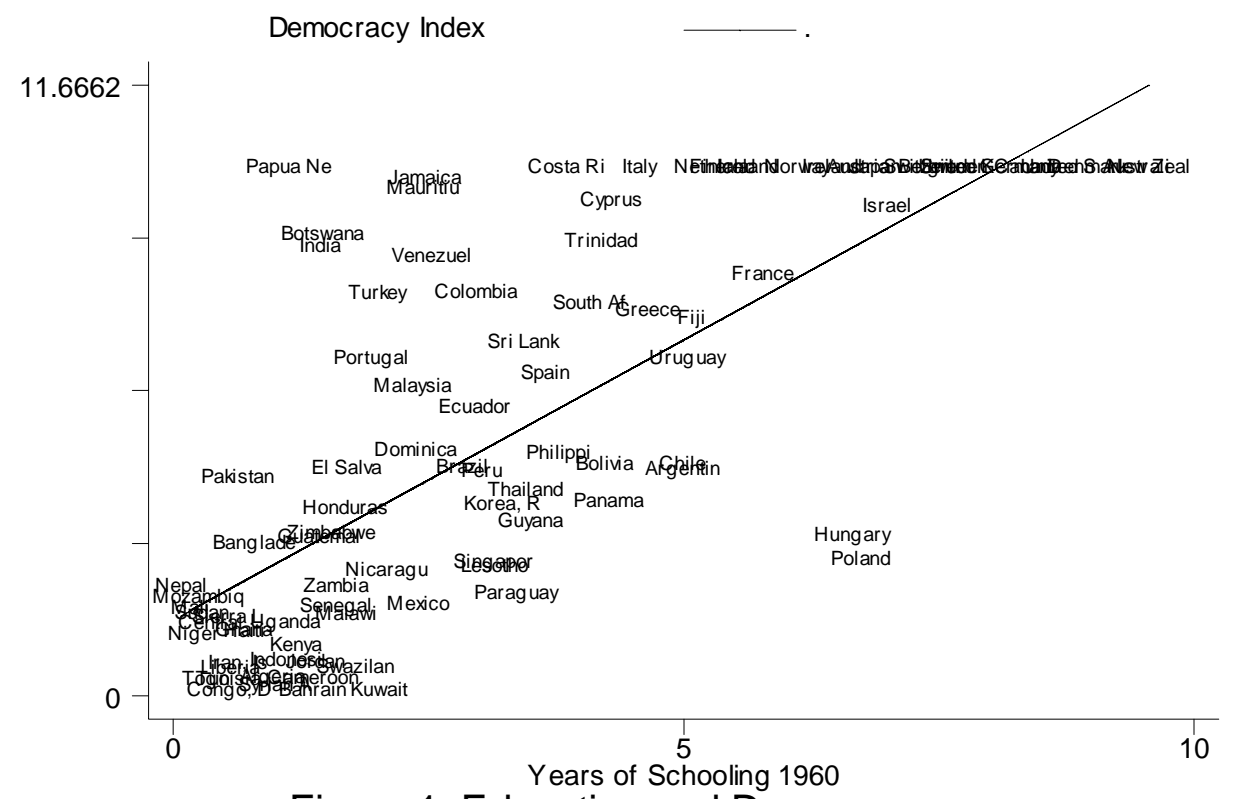

Figure 1: Education and Democracy

cdemoc

Fitted values

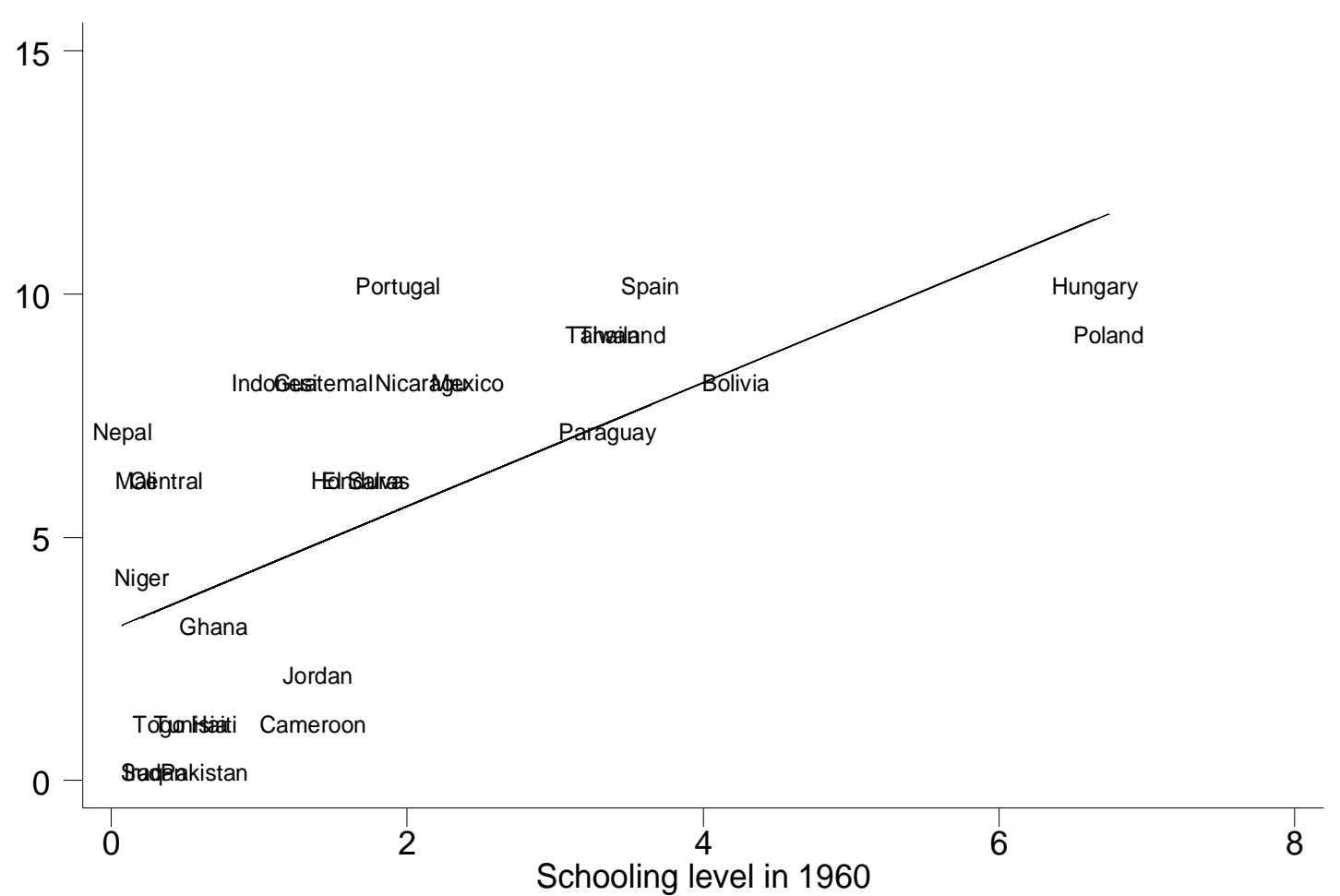

Figure 2: Schooling and the Growth of Democracy 1960-2000 


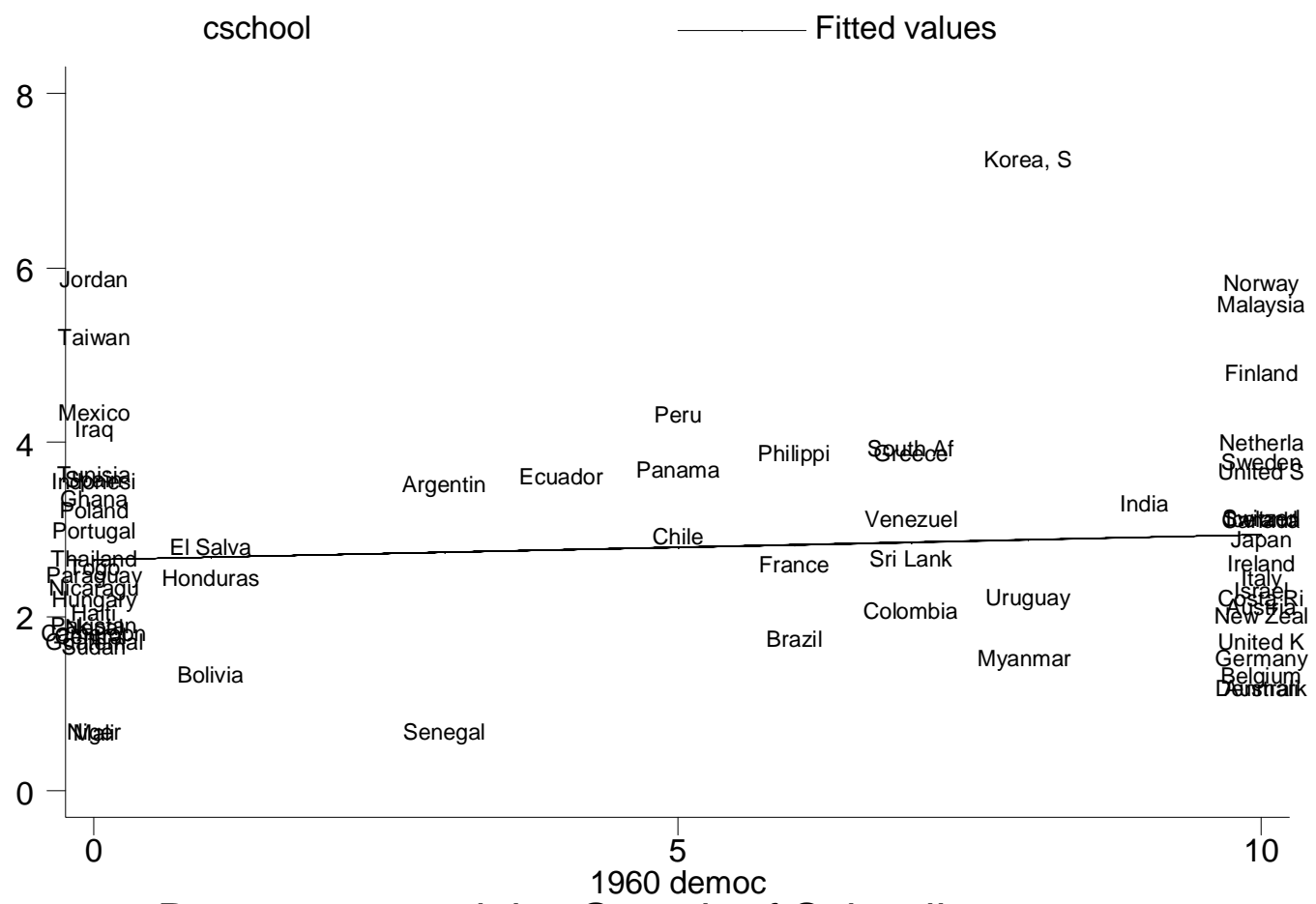

Figure 3: Democracy and the Growth of Schooling 1960-2000

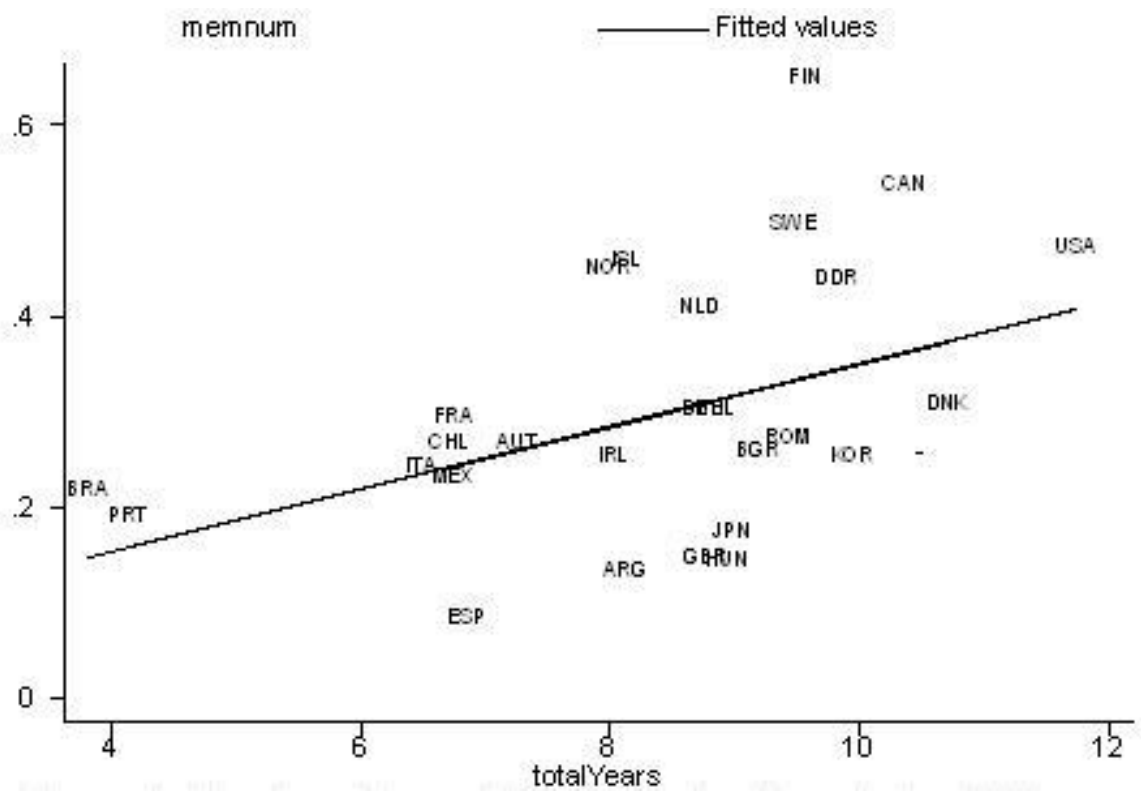

Figure 4: Membership and Education by Country in 1990 


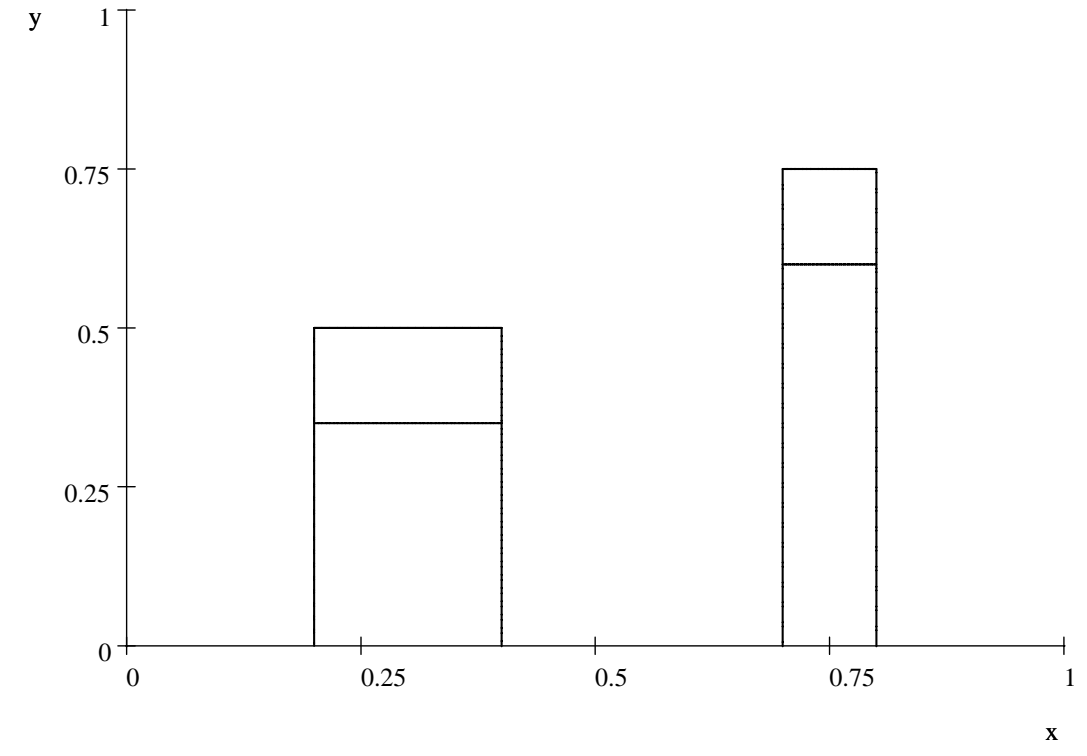

Figure 5: Support for two regimes as a function of $h$

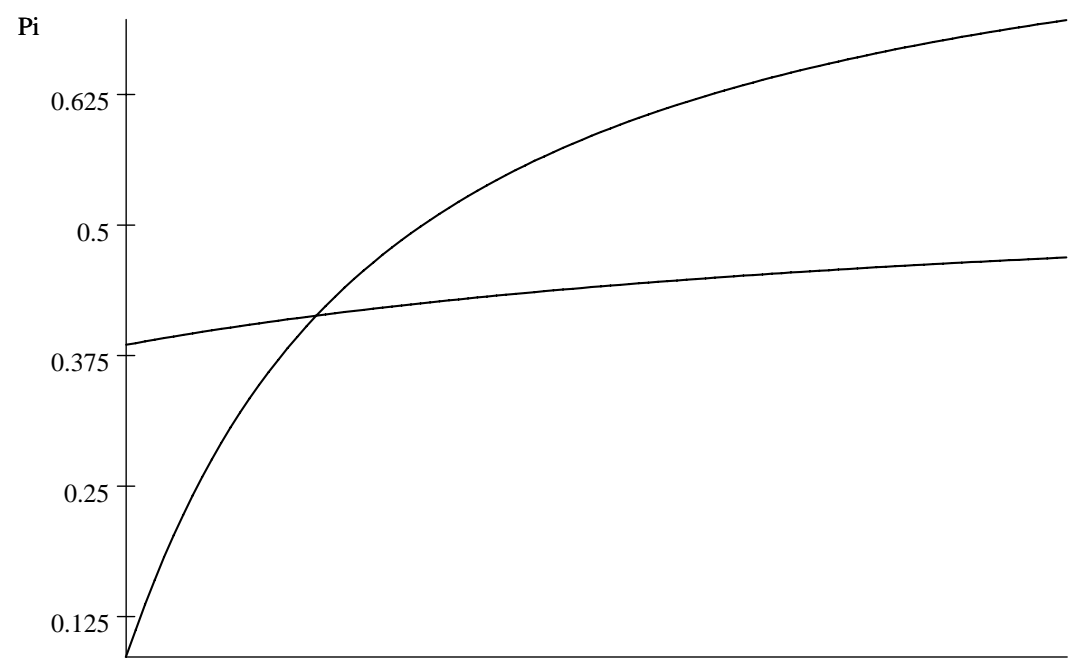

$\mathrm{h}$

Figure 6: Probability of success for a more democratic regime 


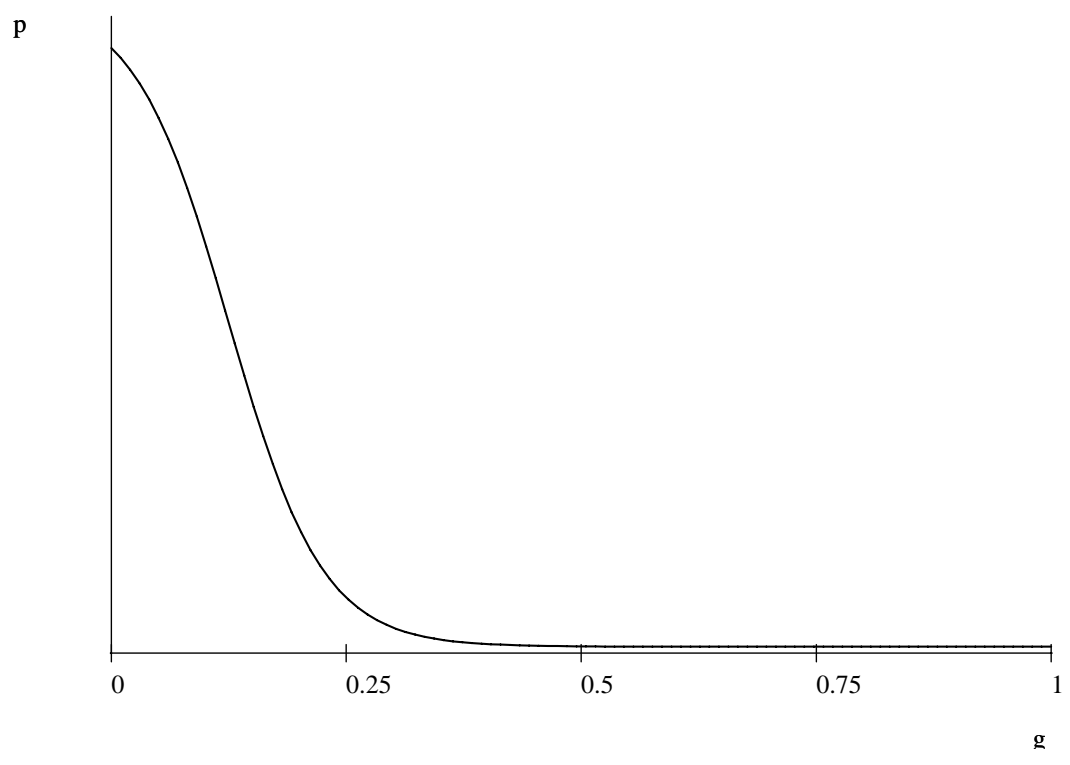

Figure 7: An example of cost function with $p^{\prime}<0$ and $p^{\prime \prime \prime}>0$

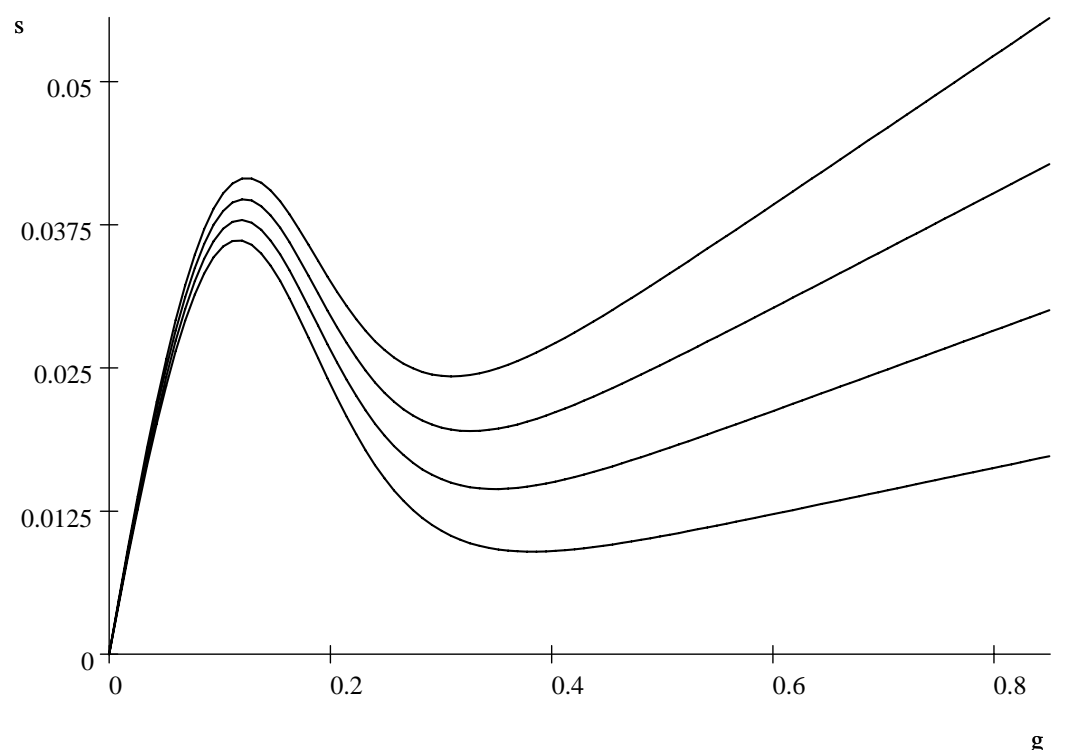

Figure 8: Support for a challenger to an oligarchy $G: g=0.15$ 


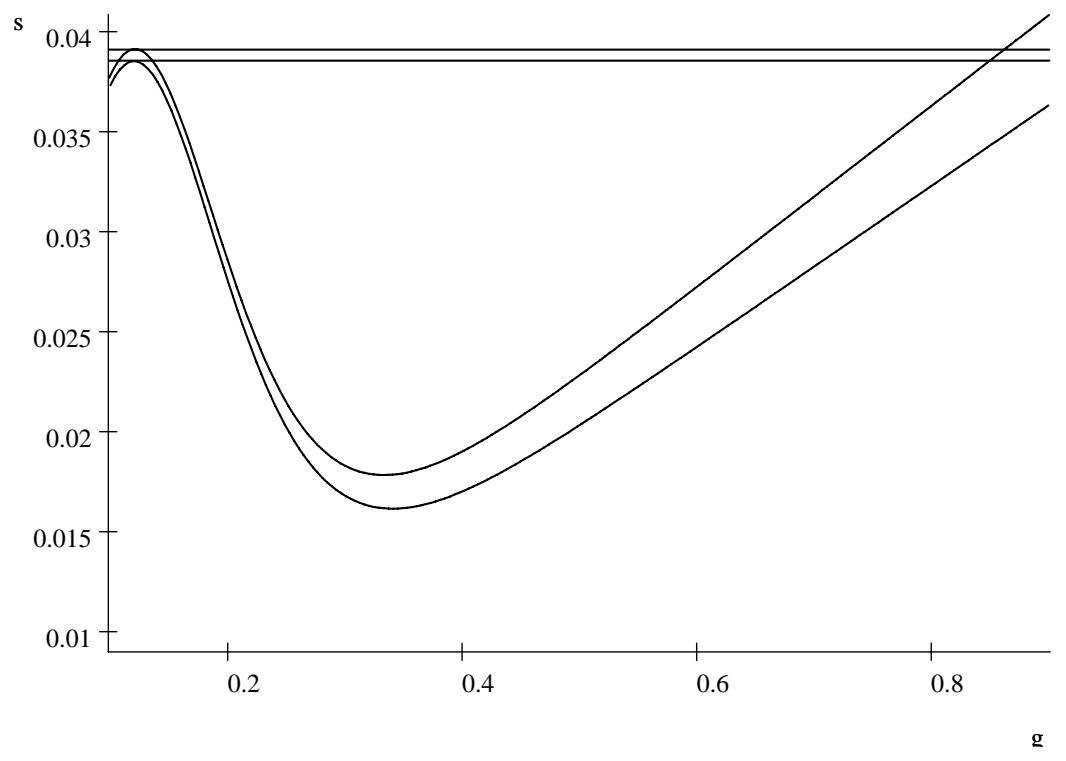

Figure 9: Discrete jump in $g^{*}$ as $h$ crosses the threshold

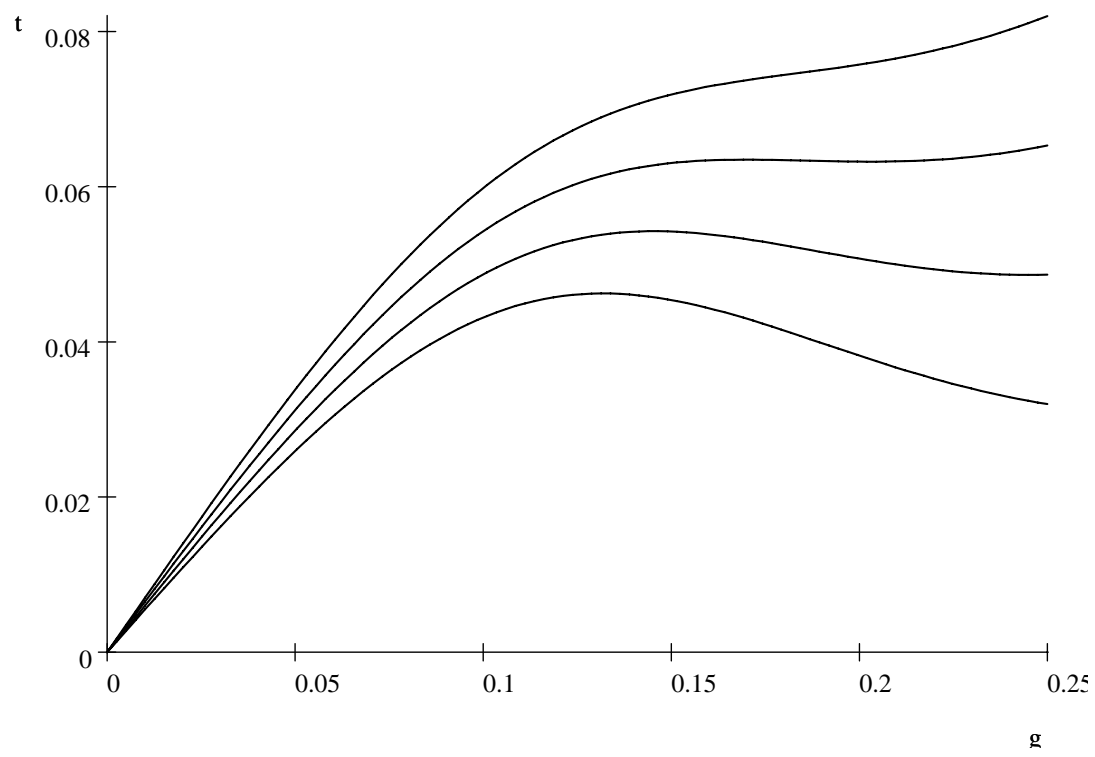

Figure 10: Support for a coup against perfect democracy 


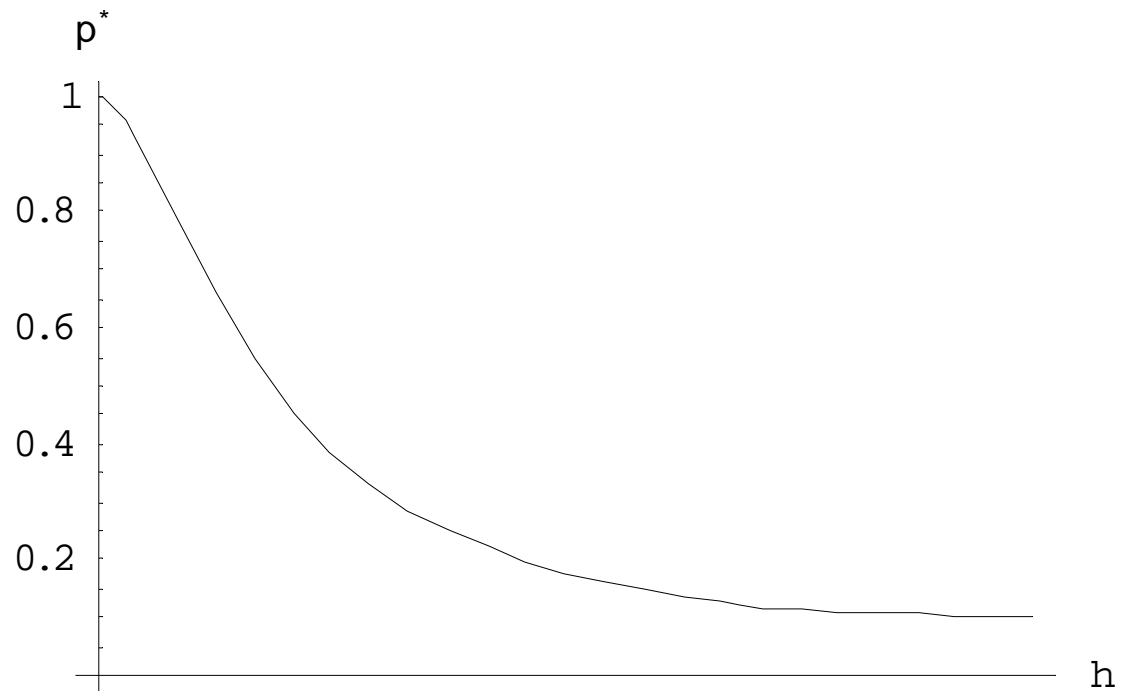

Figure 11: Maximum probability of overthrowing democracy

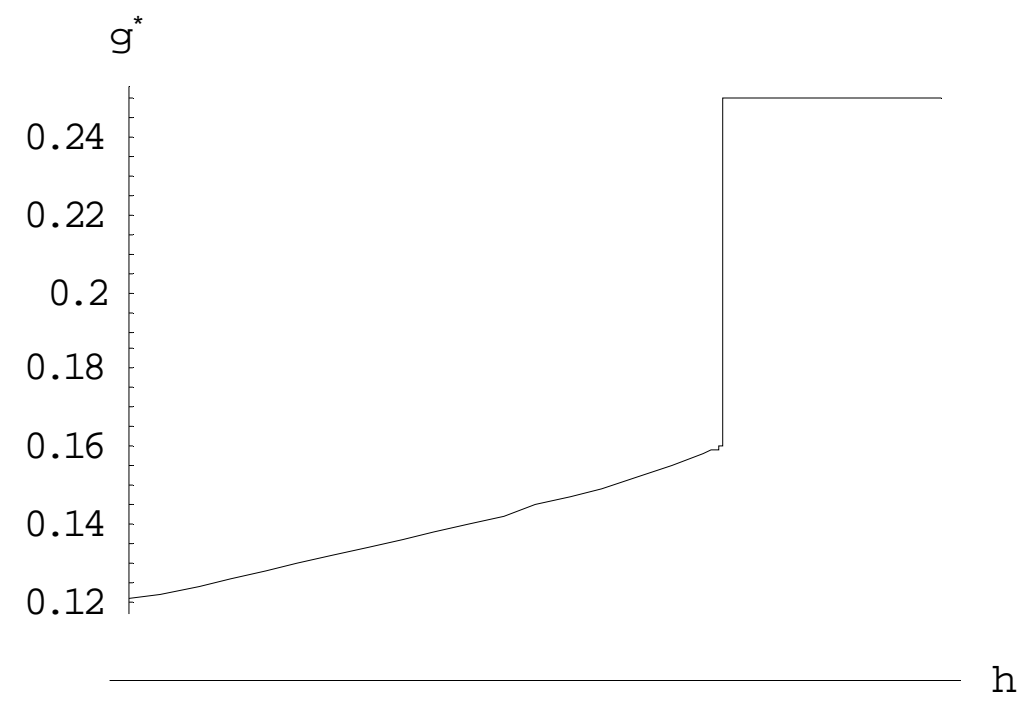

Figure 12: Size of the most effective oligarchic coup 
Table 1a - The Stability of Democracy and Dictatorship in High Education Countries (>5.0115)

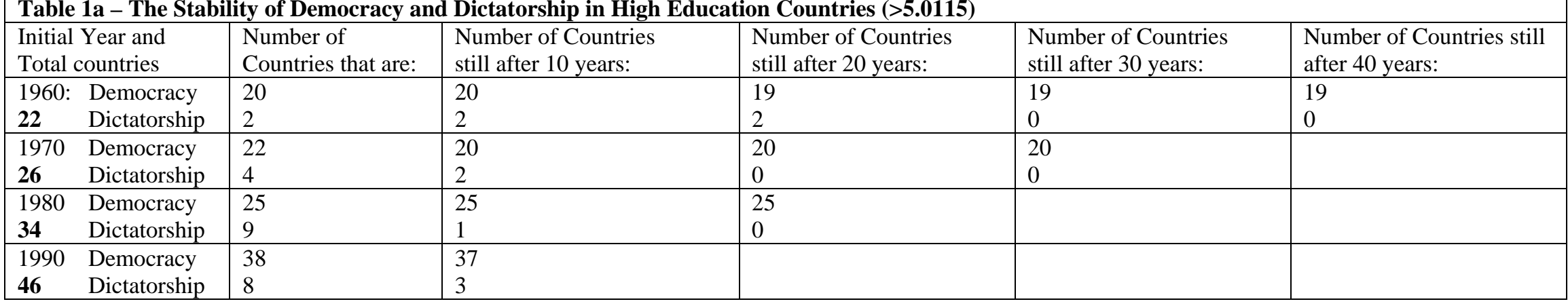

\begin{tabular}{|c|c|c|c|c|c|}
\hline $\begin{array}{l}\text { Initial Year and } \\
\text { Total countries }\end{array}$ & $\begin{array}{l}\text { Number of } \\
\text { Countries that are: }\end{array}$ & $\begin{array}{l}\text { Number of Countries still } \\
\text { after } 10 \text { years: }\end{array}$ & $\begin{array}{l}\text { Number of Countries still } \\
\text { after } 20 \text { years: }\end{array}$ & $\begin{array}{l}\text { Number of Countries still } \\
\text { after } 30 \text { years: }\end{array}$ & $\begin{array}{l}\text { Number of Countries still } \\
\text { after } 40 \text { years: }\end{array}$ \\
\hline $\begin{array}{ll}\text { 1960: } & \text { Democracy } \\
17 & \text { Dictatorship }\end{array}$ & $\begin{array}{l}11 \\
6\end{array}$ & $\begin{array}{l}6 \\
6\end{array}$ & $\begin{array}{l}5 \\
4\end{array}$ & $\begin{array}{l}5 \\
3\end{array}$ & $\begin{array}{l}5 \\
0\end{array}$ \\
\hline $\begin{array}{ll}1970 & \text { Democracy } \\
\mathbf{1 9} & \text { Dictatorship } \\
\end{array}$ & $\begin{array}{l}7 \\
12\end{array}$ & $\begin{array}{l}7 \\
10\end{array}$ & $\begin{array}{l}7 \\
5\end{array}$ & $\begin{array}{l}7 \\
1\end{array}$ & \\
\hline $\begin{array}{ll}1980 & \text { Democracy } \\
\mathbf{2 4} & \text { Dictatorship } \\
\end{array}$ & $\begin{array}{l}9 \\
15 \\
\end{array}$ & $\begin{array}{l}9 \\
12 \\
\end{array}$ & $\begin{array}{l}8 \\
6 \\
\end{array}$ & & \\
\hline $\begin{array}{ll}1990 & \text { Democracy } \\
27 & \text { Dictatorship }\end{array}$ & $\begin{array}{l}13 \\
14\end{array}$ & $\begin{array}{l}13 \\
11\end{array}$ & & & \\
\hline
\end{tabular}

\begin{tabular}{|l} 
Table 1c - The Stability of Democracy and Dictatorship in Low Education Countries $(<2.6785)$ \\
\hline
\end{tabular}

\begin{tabular}{|c|c|c|c|c|c|}
\hline $\begin{array}{l}\text { Initial Year and } \\
\text { Total countries }\end{array}$ & $\begin{array}{l}\text { Number of } \\
\text { Countries that are: }\end{array}$ & $\begin{array}{l}\text { Number of Countries still } \\
\text { after } 10 \text { years: }\end{array}$ & $\begin{array}{l}\text { Number of Countries still } \\
\text { after } 20 \text { years: }\end{array}$ & $\begin{array}{l}\text { Number of Countries still } \\
\text { after } 30 \text { years: }\end{array}$ & $\begin{array}{l}\text { Number of Countries still } \\
\text { after } 40 \text { years: }\end{array}$ \\
\hline $\begin{array}{ll}\text { 1960: } & \text { Democracy } \\
\mathbf{1 8} & \text { Dictatorship } \\
\end{array}$ & $\begin{array}{l}4 \\
14 \\
\end{array}$ & $\begin{array}{l}2 \\
13 \\
\end{array}$ & $\begin{array}{l}2 \\
13 \\
\end{array}$ & $\begin{array}{l}2 \\
11 \\
\end{array}$ & $\begin{array}{l}2 \\
5\end{array}$ \\
\hline $\begin{array}{ll}1970 & \text { Democracy } \\
\mathbf{2 1} & \text { Dictatorship }\end{array}$ & $\begin{array}{l}3 \\
18\end{array}$ & $\begin{array}{l}1 \\
18\end{array}$ & $\begin{array}{l}1 \\
16\end{array}$ & $\begin{array}{l}1 \\
9\end{array}$ & \\
\hline $\begin{array}{ll}1980 & \text { Democracy } \\
\mathbf{2 4} & \text { Dictatorship }\end{array}$ & $\begin{array}{l}4 \\
20\end{array}$ & $\begin{array}{l}3 \\
17\end{array}$ & $\begin{array}{l}2 \\
9\end{array}$ & & \\
\hline $\begin{array}{ll}1990 & \text { Democracy } \\
\mathbf{1 6} & \text { Dictatorship }\end{array}$ & $\begin{array}{l}5 \\
11 \\
\end{array}$ & $\begin{array}{l}2 \\
4 \\
\end{array}$ & & & \\
\hline
\end{tabular}




\begin{tabular}{|c|c|c|c|c|c|c|c|}
\hline Table 2 - The Effect of Education on Democracy, 1865-2000 \\
\hline Independent Variable & $\begin{array}{c}1960-2000 \\
\text { Only }\end{array}$ & $\begin{array}{c}1960-2000 \\
\text { Only }\end{array}$ & $\begin{array}{c}1960-2000 \\
\text { Only }\end{array}$ & $1865-2000$ & $1865-2000$ & $\begin{array}{c}1865-2000 \text { with } \\
\text { no country } \\
\text { clustering }\end{array}$ & $\begin{array}{c}1865-2000 \text { with } \\
\text { country } \\
\text { clustering }\end{array}$ \\
\hline Secondary Coefficient & - & 0.181 & & 0.290 & - & 0.238 & 0.499 \\
\hline & & $(0.053)$ & & $(0.046)$ & & $(0.496)$ & $(0.136)$ \\
\hline University Coefficient & - & - & 0.633 & - & 0.850 & 0.532 & 1.825 \\
\hline & & & $(0.196)$ & & $(0.172)$ & $(0.183)$ & $(0.430)$ \\
\hline Years of Schooling & -0.237 & - & - & - & - & - & - \\
\hline Country Fixed Effects & $(0.150)$ & & & & & & Yes \\
\hline Year Fixed Effects & Yes & Yes & Yes & Yes & Yes & Yes & Yes \\
\hline Countries & 101 & 132 & 132 & 133 & 133 & 133 & 133 \\
\hline Years & 9 & 9 & 9 & 25 & 25 & 25 & 25 \\
\hline Observations & 777 & 691 & 691 & 1316 & 1316 & 1316 & 1316 \\
\hline R-Squared & 0.799 & 0.879 & 0.879 & 0.788 & 0.786 & 0.790 & 0.210 \\
\hline
\end{tabular}

Dependent variable is the democracy score from: Jaggers, Keither and Monty G. Marshall (2003). "Polity IV Project.” Center for

International Development and Conflict Management, University of Maryland. Online at

http://www.cidcm.umd.edu/inscr/polity/index.htm.

Average Years of Schooling data (column 1) from: Barro, Robert J. and Jong-Wha Lee, International Data on Educational Attainment:

Updates and Implications. Source: Barro and Lee (2000) Data posted on http://www.cid.harvard.edu/ciddata/ciddata.html.

Enrollment data (columns 2-7) from: Banks, Arthur S (2004). Cross National Time-Series Data Archive. CD-ROM. Binghamton, New

York: Arthur S. Banks.

Data are every 5 years from 1865 to 2000 with the exception of 1915, 1940, and 1945, for which data are unavailable. 


\begin{tabular}{|c|c|c|c|c|c|c|c|}
\hline & $\begin{array}{l}\text { Attended church or } \\
\text { other place of worship }\end{array}$ & $\begin{array}{c}\text { Attended a } \\
\text { class or seminar }\end{array}$ & $\begin{array}{c}\text { Worked on a } \\
\text { community project }\end{array}$ & $\begin{array}{l}\text { Wrote a letter } \\
\text { to the editor }\end{array}$ & $\begin{array}{c}\text { Contacted a } \\
\text { public official }\end{array}$ & $\begin{array}{l}\text { Are you a } \\
\text { registered voter? }\end{array}$ & $\begin{array}{l}\text { Gave someone the } \\
\text { finger while driving }\end{array}$ \\
\hline Dependent variable mean & 22.7 & 4.8 & 2.4 & 0.5 & 2.1 & $88 \%$ & 2.1 \\
\hline High School grad & $\begin{array}{l}0.1794 \\
{[12.22]^{* *}}\end{array}$ & $\begin{array}{l}0.181 \\
{[7.01]^{* *}}\end{array}$ & $\begin{array}{l}0.1209 \\
{[8.69]^{* *}}\end{array}$ & $\begin{array}{l}0.0353 \\
{[1.88]}\end{array}$ & $\begin{array}{l}0.1044 \\
{[2.15]^{*}}\end{array}$ & $\begin{array}{l}0.4673 \\
{[7.89]^{* *}}\end{array}$ & $\begin{array}{l}-0.1413 \\
{[3.01]^{* *}}\end{array}$ \\
\hline College grad & $\begin{array}{l}0.1593 \\
{[14.45]^{* *}}\end{array}$ & $\begin{array}{l}0.4011 \\
{[23.18]^{* *}}\end{array}$ & $\begin{array}{l}0.1997 \\
{[19.10]^{* *}}\end{array}$ & $\begin{array}{l}0.0865 \\
{[6.50]^{* *}}\end{array}$ & $\begin{array}{l}0.1828 \\
{[4.65]^{* *}}\end{array}$ & $\begin{array}{l}0.1632 \\
{[4.63]^{* *}}\end{array}$ & $\begin{array}{l}-0.159 \\
{[5.84]^{* *}}\end{array}$ \\
\hline Survey year & $\begin{array}{l}-0.018 \\
{[14.38]^{* *}}\end{array}$ & $\begin{array}{l}-0.0169 \\
{[3.27]^{* *}}\end{array}$ & $\begin{array}{l}-0.0069 \\
{[5.85]^{* *}}\end{array}$ & $\begin{array}{l}0.0002 \\
{[0.10]}\end{array}$ & & & $\begin{array}{l}0.04 \\
{[1.69]}\end{array}$ \\
\hline Female & $\begin{array}{l}0.2515 \\
{[27.66]^{* *}}\end{array}$ & $\begin{array}{l}0.0282 \\
{[1.92]}\end{array}$ & $\begin{array}{l}0.0733 \\
{[8.51]^{* *}}\end{array}$ & $\begin{array}{l}0.005 \\
{[0.45]}\end{array}$ & $\begin{array}{l}-0.1546 \\
{[4.77]^{* *}}\end{array}$ & $\begin{array}{l}0.1167 \\
{[3.77]^{* *}}\end{array}$ & $\begin{array}{l}-0.2101 \\
{[8.74]^{* *}}\end{array}$ \\
\hline Age & $\begin{array}{l}0.0103 \\
{[36.12]^{* *}}\end{array}$ & $\begin{array}{l}-0.0111 \\
{[24.02]^{* *}}\end{array}$ & $\begin{array}{l}0.0056 \\
{[20.55]^{* *}}\end{array}$ & $\begin{array}{l}0.0016 \\
{[4.66]^{* *}}\end{array}$ & $\begin{array}{l}0.0027 \\
{[2.50]^{*}}\end{array}$ & $\begin{array}{l}0.0119 \\
{[12.18]^{* *}}\end{array}$ & $\begin{array}{l}-0.0122 \\
{[16.34]^{* *}}\end{array}$ \\
\hline Black & $\begin{array}{l}0.0983 \\
{[4.61]^{* *}}\end{array}$ & $\begin{array}{l}-0.0549 \\
{[1.84]}\end{array}$ & $\begin{array}{l}0.0095 \\
{[0.47]}\end{array}$ & $\begin{array}{l}0.0138 \\
{[0.57]}\end{array}$ & $\begin{array}{l}-0.1619 \\
{[1.64]}\end{array}$ & $\begin{array}{l}0.1167 \\
{[2.10]^{*}}\end{array}$ & \\
\hline Asian & $\begin{array}{l}-0.303 \\
{[5.61]^{* *}} \\
\end{array}$ & $\begin{array}{l}0.1815 \\
{[2.74]^{* *}}\end{array}$ & $\begin{array}{l}-0.0641 \\
{[1.25]}\end{array}$ & $\begin{array}{l}0.0607 \\
{[1.06]}\end{array}$ & $\begin{array}{l}0.0778 \\
{[0.15]}\end{array}$ & $\begin{array}{l}-0.533 \\
{[4.61]^{* *}} \\
\end{array}$ & \\
\hline Other & $\begin{array}{l}-0.1549 \\
{[2.76]^{* *}}\end{array}$ & $\begin{array}{l}0.0918 \\
{[1.27]}\end{array}$ & $\begin{array}{l}0.0688 \\
{[1.29]}\end{array}$ & $\begin{array}{l}0.3124 \\
{[5.01]^{* *}}\end{array}$ & $\begin{array}{l}-0.1327 \\
{[0.46]}\end{array}$ & $\begin{array}{l}-0.0172 \\
{[0.12]}\end{array}$ & \\
\hline Log income in 2000 dollars & $\begin{array}{l}0.02 \\
{[3.08]^{* *}}\end{array}$ & $\begin{array}{l}-0.0659 \\
{[6.17]^{* *}}\end{array}$ & $\begin{array}{l}0.052 \\
{[8.45]^{* *}}\end{array}$ & $\begin{array}{l}-0.0181 \\
{[2.29]^{*}}\end{array}$ & $\begin{array}{l}0.0063 \\
{[0.20]}\end{array}$ & $\begin{array}{l}0.1299 \\
{[5.84]^{* *}}\end{array}$ & $\begin{array}{l}-0.0038 \\
{[0.22]}\end{array}$ \\
\hline Missing income data & \begin{tabular}{|l|}
-0.0243 \\
{$[1.04]$} \\
\end{tabular} & $\begin{array}{l}-0.0149 \\
{[0.48]} \\
\end{array}$ & $\begin{array}{l}0.0085 \\
{[0.39]} \\
\end{array}$ & $\begin{array}{l}0.0295 \\
{[1.14]}\end{array}$ & $\begin{array}{l}-0.1134 \\
{[0.83]}\end{array}$ & $\begin{array}{l}0.0164 \\
{[0.19]} \\
\end{array}$ & $\begin{array}{l}0.0143 \\
{[0.27]} \\
\end{array}$ \\
\hline Constant & $\begin{array}{l}34.7132 \\
{[14.01]^{* *}}\end{array}$ & $\begin{array}{l}34.6147 \\
{[3.37]^{* *}}\end{array}$ & $\begin{array}{l}12.7943 \\
{[5.44]^{* *}}\end{array}$ & $\begin{array}{l}-0.4271 \\
{[0.09]}\end{array}$ & $\begin{array}{l}-0.2611 \\
{[0.85]}\end{array}$ & $\begin{array}{l}-2.4316 \\
{[10.15]^{* *}}\end{array}$ & $\begin{array}{l}-79.0522 \\
{[1.67]}\end{array}$ \\
\hline Observations & 47459 & 18888 & 47808 & 30710 & 3229 & 3617 & 6747 \\
\hline R-squared & 0.05 & 0.07 & 0.02 & 0 & 0.02 & 0.08 & 0.05 \\
\hline
\end{tabular}

Notes: Absolute value of t statistics in brackets. * Indicated significance at 5\%; ** Indicates significance at 1\%. Data from DDB Needham 